\title{
A COUNTER-HISTORY OF ANTITRUST LAW
}

\author{
Rudolph J. Peritz*
}

TABLE OF CONTENTS

Introduction

I. First Disagreement about Competition as Constituting the Formative Period: Literalists and Rule of Reasonists...... 269

A. The Orthodox View: The Impossibility of Literalism ... 269

B. A Genealogical View: Property Rights in Restraint of Competition

II. Second Disagreement about Competition as Constituting Antitrust's Middle Period: The Rule of Reason.......... 279

A. The Orthodox View: Balancing Competitive Effects .... 279

B. A Genealogical View: Balancing Property Rights and Competition Policy............................... 285

1. Price-fixing as Illegal Per Se. ................. 286

2. Price-fixing as a Reasonable Restraint of Trade. .... 288

3. Price-fixing as Legal Per Se.................. 295

III. Third Disagreement about Competition as Constituting Antitrust's Current Period: Efficiency and Populism ...... 300

A. The Price Theoretical View: Solving the Paradox of Competition .................................. 301

B. A Genealogical View: Competition and Its Relationships to Efficiency and Populism ..................... 302

1. The Relationship Between Wealth Maximization and Competition.............................. 303

2. The Relationship Between Populism and Competition. .................................. 307

IV. Recent Scholarly Attention to the Formative Period:

Toward a Fourth Disagreement about Competition........ 311

Conclusion ...................................... 317

* Professor of Law, New York Law School. Some of the research for this Article was funded by a New York Law School Faculty Summer Research Grant. A version of this Article was presented at Duke Law School's Conference on Frontiers of Legal Thought, a well-organized and energizing enterprise "dedicated to exploring new directions in minority, feminist, and critical legal thought and practice." Special acknowledgement for the conference's success should go to Duke law students Tony Taibi and Dana Lesemann. 


\section{INTRODUCTION}

When we make antitrust arguments, we employ the rhetoric of competition. We simply take for granted the received learning that competition policy (and its celebrated logic of efficiency) has always provided the ground for antitrust arguments. 1

But this longstanding rhetorical consensus has settled nothing. As trained producers of antitrust arguments, we know that the rhetoric of competition allows for the expression of deep-seated disagreements about competition pohicy. Take, for exainple, arguments for "free competition." To recognize the conflict lodged in calls for free competition, we need go no further than an inquiry about the restraining inechainsin: What do we want to free competition from? Do we want to free it from governmental power? Or froin inarket power? If we are concerned with governmental interference with markets, then, for exainple, any Department of Justice intervention to reform a inarket process or overturn its consequences is bad. If, on the other hand, we are concerned with market power, then government participation can be good when it dissipates that power. If these alternatives appear to offer the possibility of clear pohicy choice, then consider the more difficult and more realistic form of the question about free competition: How do we inake policy that reflects distrust of both kinds of power? ${ }^{2}$

The dilemma of "free competition" is just one of many normative conflicts captured in the rhetoric of competition. ${ }^{3}$ Although the foregoing formulation might seein new, we all understand antitrust history as a series of attempts to balance the normative implications of competition

1. For the only recent questioning of the assumption about the unrivaled policy of competition, see Peritz, The "Rule of Reason" in Antitrust Law: Property Logic in Restraint of Competition, 40 HAastings L.J. 285 (1989). See also Northern Sec. Co. v. Umited States, 193 U.S. 197, 403 (1904) (Holmes, J., dissenting) (observing that the Sherman Act "says nothing about competition").

2. This ideological problem provides currency for the idea of anti-trust, an idea that need not be limited to the historical emergence and disappearance of a particular legal form (or fiction) called a "trust." Instead, it makes good ideological sense, given the imdividualistic (liberal) tradition marked by Jolm Locke, Immanuel Kant, and others, that there would and should appear a statute institutionalizing anti-trust of anti-monadic power, regardless of that power's location in the public or private spheres, as we imagine them today. On the other hand, Locke, Hobbes, and other contractarians sought to legitimize the transition from monadic natural rights to societal coercion through the fictive mechanism of agreement. Given this founding myth of social contract, how can a statute institutionalize an economy where "contract[s] . . . im restraint of trade," are proscribed? Sherman Act § 1, 15 U.S.C. $\$ 1$ (1988) (effective July 2, 1890). Isn't the contractarian formation of society by its nature a restraint of trade? Isn't that its purpose? If so, then it seems that wc should ouly distrust monadic power, power exercised by individuals, whose strength prevails despite the social compact creating a community of interest.

3. The logic of efficiency has done no better. For an analysis of the logic's incoherence, as well as its failure to rationalize one area of antitrust, see Peritz, The Predicament of Antitrust Jurisprudence: Economics and the Monopolization of Price Discrimination Angument, 1984 DUKE L.J. 1205. 
policy. In short, our framework for reading antitrust doctrine is the historical development of the Supreme Court's "rule of reason" jurisprudence. Two fundamental failings, however, cliaracterize this familiar history of the "rule of reason"-one failing well-known and the other only recently recognized.

The notorious problem with the "rule of reason" is its open-endedness, its incoherence, its unrealizability. Judicial balancing of competitive effects under the "rule of reason" has called for argument about secondary policy imphications, such as the need for fair methods of competition or the efficiency effects of competitive inarkets. But what have we meant by each of these implied policies? And which of them apphes to an evaluation of market conduct, such as fixing prices or buying rivals? When is an implication so important, or a combination so consequential, or a transgression so threatening, that the conduct should always be illegal? If not illegal per se, how do we weigh and balance these elements in a rule of reason analysis? To use familiar antitrust discourse, how do we determine (consistently) the effects on competition?

There is a second problem with this familiar view of antitrust history as a series of attempts to balance social values implicated in the rhetoric of competition. Despite its apparent open-endedness, the rhetoric of coinpetition has restricted our understanding of antitrust law in two influential ways. First, because the economic logic of price theory has persuaded inany of us to accept its claims of unrivaled precision and logical structure, we presume (or fear) that arguments founded in social values but not reflected in the current antitrust discourse of economics ${ }^{4}$ simply cannot be adjudicated in a structured way. But don't be misled. There are lots of alternative structures. The conundrum of "free competition" can illustrate one alternative structure: The desire for competi-tion free of government power can be understood as an impulse toward the value of individual liberty. On the other liand, the desire for competition free of market power is reflected in tlie conventional models of perfect and workable competition-that is, in a commitment to equality in the marketplace. A structured analysis of competition policy based on these impulses toward liberty and equality can lrelp us begin to make sense of antitrust law and policy, including the listorical relationship

4. This discourse primarily focuses on efficiency, though more recently it has included redistribution in the narrow sense of consumer well-being. See generally Lande, Wealth Transfers as the Original and Primary Concern of Antitrust: The Efficiency Interpretation Challenged, 34 HASTINGS L.J. 65 (1982) (Congress' antitrust objective was to prevent the formation of market power and super-competitive consumer prices). For an extended analysis of the analytical inadequacies and rhetorical overcompensations of soine price theorists in the colonized area of price discrimination, see Peritz, supra note 3. 
between competition policies and efficiency logics. But it is only a beginning.

Reinembering commitments to hiberty and equality as factors in the production of competition rhetoric is helpful. It is inadequate, though, to the task of understanding antitrust history, for the rhetoric of competition has confined our understanding of antitrust law im a second way as well. The steady din of competition rhetoric has numbed our faculties and kept us from remembering that competition policy has never been the sole normative ground for antitrust laws. Fresh readings of case materials, legislative histories, and other texts constituting the discourse of antitrust deinonstrate that antitrust law always has been produced by a fundamental tension between competition policy and common law property rights. 5 In other words, the rhetoric of coinpetition has obscured the full scope of antitrust's history of nornative conflict and, thus, the full scope of familiar terms such as fair competition or efficiency. To understand these terms of engagement, to uncover the relationship between competition policy and efficiency logics, and to develop a satisfactory metliodology that clarifies antitrust without the nornative distortion of current price theory, our analysis must take into account one hundred years of claims founded in common law property rights.

Take, for example, the theme of "fair profit" heard throughout the congressional debates over the Sherinan Act:

[E]very man in busmess ... has a right, a legal and moral right, to obtain a fair profit upon his business and his work; and if he is driven by fierce competition to a spot where his business is unremunerative, I believe it is his right to combime for the purpose of raising prices until they shall be fair and reinunerative. ${ }^{6}$

In short, the force of competition was sometimes seen as having destructive effects. Not only in the congressional debates but also in Supreine Court doctrine, competition was considered ruinous when it destroyed a property owner's right to a fair profit on his work.

For a recent variation on the fair profit theine, recall for a moinent the Supreme Court's turn to a "free rider" rationale for perinitting manufacturers to impose restramts on their distributors and dealers:

[N] ew manufacturers ... can use the restrictions in order to induce competent and aggressive retailers ... to engage in promotional activi-

5. See generally Peritz, supra note 1, at 289-90, 303-24 (discussing the conflict between state regulation of competition and the rights of property owners).

6. 21 CoNG. Rec. 2730 (1890) (statement of Sen. Platt); see also Peritz, supra note 1, at 297. 303 (discussing the logic of "fair profit," i.e., that a fair return on one's labor is a social good worthy of government enforcement); Peritz, A Genealogy of Vertical Restraints Doctrine, 40 HASTINGS L.J. 511, 516-27 (1989) (analyzing how the Court in its early interpretations of the Sherman Act viewed the roles of competition and "fair price"). 
ties or to provide service and repair facilities necessary to the efficient marketing of their products. ${ }^{7}$

In other words, a inanufacturer can protect the promoting retailer's expectation of a fair profit earned from its promotional work by, for example, granting it an exclusive territory or, in the alternative, simply terminating price cutting rivals. As Posner and Easterbrook have written, "When people use a valuable good [such as the goodwill created by promotional work] without paying for it, economists call them free riders."8 In sum, the free-rider rationale reflects concern over uncompensated takings of another's property-soinething akin to theft. These calls for a right to a fair profit, spanning almost a century, are examples of an extensive body of antitrust doctrines inspired by the normative appeal of common law property rights. ${ }^{9}$

Such conflict may be surprising mitially, given the conventional wisdom that competitive markets depend upon property rights: Without the freedom to sell or exchange one's property, there can be no competition. While this notion remams viable, it has become equally clear that there is another facet to the historical relationship between competition policies and private property rights-a facet that reflects a conflict co-extensive with the dependency. One fundamental dispute, often repeated in the past century of antitrust argument, crystallizes this tension: On the one hand, competition policy calls for the enjoining of mergers that result in firms whose market power might allow them to dominate their rivals. On the other hand, prohibiting owners from selling their business impinges on their fundamental right to sell or exchange their property. This minimalist rendering of a conflict between competition policy and common law property rights is an accurate abstract of the opimions published in the well-known case of Northern Securities Co. v. United States. ${ }^{10}$ This conflict represents one encounter in an ongoing struggle between two rhetorics, two sets of assumptions and behefs about antitrust law. ${ }^{11}$ It is this struggle that has produced antitrust discourse.

In hight of these findings, I beheve we can make good sense of antitrust discourse and competition policy without submitting to price theory's impoverished ethic of wealth maximization. Moreover, we can

7. Continental T.V., Inc. v. GTE Sylvania Inc., 433 U.S. 36, 55 (1977). For an extended analysis of the free rider rationale, see Peritz, supra note 6, at 554-74.

8. R. POSNER \& F. EASTERBROOK, ANTITRUST LAW 177 (2d ed. 1984).

9. For full analyses of the tensions between competition policy and common law property rights and explanations of their joint production of doctrines, including the free rider rationale, see Peritz, supra note 6.

10. 193 U.S. 197 (1904). See Peritz, supra note 1, at 321-36.

11. It can also be understood in terms of the tension enbodied in the notion of "free competition," the conflict between inpulses toward liberty (of contract) and equality (of marketplace rivals). 
learn something new about the relationship between wealth maximization and competition policy. I propose that we can make antitrust law workable $\mathrm{e}^{12}$ by viewing it as the product of tensions between the rhetorics of competition policy and private property rights, each rhetoric animated by impulses toward liberty and equality. This structured analysis of antitrust discourse, which I call a "genealogy" or a "counter-history,"13 can sharpen our understanding of antitrust law, mcluding the volatile relationship between competition policy and efficiency logic. It does not require the sacrifice of antitrust's traditional pohtical econoiny of value pluralism. ${ }^{14}$ Rather, this framework of two rhetorics or logics in productive conflict can revitalize an antitrust economy of pluralisin by challenging the view that unfettered competition represents the only positive norm for antitrust. Further, this challenge clears the way for disputing the related claim that concern about wealth transfers, special solicitude for small business, or other so-called "anti-coinpetition" sentiments constitute negative values that slould or can be subordinated. Instead, a genealogy helps us remeinber that these sentiments, as well as tlose traditionally associated with competition, are historical products of tensions between coinpetition policy and common law property rights. Antitrust doctrime and policy make sense when understood as products of the tension between these two social forces.

We have learned to compreliend antitrust history as a series of disagreements about competition policy. Taking this view as my framework for this paper, I divide antitrust discourse into three historical periods, eacli era typified by one form of disagreennent over competition policy. But no form ever has succeeded its forerunner, as one paradigm might be

12. My use of the term "workable" is not intended as an allusion either to the body of economic analysis founded in the notion of "workable competition" or to the antitrust policy analysis based on that body of work. See generally REPORT OF THE ATTORNEY GENERAL's NATIONAL COMMITTEE TO STUDY ANTTTRUST LAWS $320-39$ (1955) [hereinafter 1955 ATTORNEY GENERAL's REPORT]; P. AREEDA, ANTITRUST ANALYSIS 40 (3d ed. 1981); Clark, Toward a Concept of Workable Competition, 30 AM. ECON. REV. 241 (1940); Stocking, The Rule of Reason, Workable Competition, and Monopoly, 64 YALE L.J. 1107 (1955). Nor is it intended as an allusion to other recent renditions of "workability." See, e.g., Arthur, Workable Antitrust Law: The Statutory Approach to Antitrust, 62 TUL. L. REv. 1163 (1988) (arguing that moving from a constitutional approach to a statutory approach can make antitrust law workable); Easterbrook, Workable Antitrust Policy, 84 Mich. L. REv. 1696 (1986) (price theory as basis for workable antitrust policy).

13. See generally M. Foucault, Nietzsche, Genealogy, History, in LANGUAGE, CounTERMemory, Practice: Selected Essays 139-64 (D. Bouchard ed. 1977); M. Foucault, Two Lectures, in POWER/KNOWLEDGe: Selected INTERviews \& OTHER Writtings 78-108 (C. Gordon ed. 1980). Cf. F. NieTzSChe, The USE AND ABUSE OF History (1874) (A. Collins trans. 1949); H. White, Metahistory: The Historical Imagination In NiNETEENTH-Century EURope 4142, 331-74 (1973) (Nietzschean historiography).

14. For a summary of this political econouny of pluralisin, see infra text aecompanying notes 65-80. For a snapshot of this dynamic process of antitrust discourse production, see Peritz, supra note 1 , at $336-41$. 
thought to displace its predecessor. ${ }^{15}$ Rather, we have welcomed each new form as an illumination or supplement to an evolving policy of competition. ${ }^{16}$ Thus, we have retained all three forms as familiar ingredients in our current antitrust discourse.

There are four parts to this Article. Parts I, II, and III set forth dual accounts of three historical periods of antitrust discourse-accounts of the production factors for antitrust argument. Each of the first three Parts recounts a dual history of antitrust discourse-the orthodox history of one disagreement over competition policy, followed by a counterhistory or genealogy of the disagreement. Part IV reports the recent effusion of scholarly attention to antitrust's formative years and describes its relationship to a genealogical approach. The Article concludes with a few remarks about the prospects for freeing antitrust argument from the prison of price theory, and for rcconstituting antitrust as public interest law.

\section{First Disagreement About Competition as Constituting THE Formative PERIOD: LITERALISTS AND RULE OF REASONISTS}

In the twenty years following the Sherman Act's passage, two factions on the Supreme Court held conflicting convictions about the statute. According to the orthodox view of those early years, literalists and rule of reasonists disagreed over a technical inatter-the prospect of reading the statute literally. In sharp contrast, a genealogical approach leads to an account of the factional dispute as a fundamental disagreement about the relationship between congressional competition policy and common law property rights.

\section{A. The Orthodox View: The Impossibility of Literalism}

Although federal antitrust law originated in a statute-the Sherman Act of $1890^{17}$-judges and scliolars have viewed the statute as little more than a congressional mandate to develop a federal common law of coinpetition. ${ }^{18}$ Thus, it is not surprising that we pay inore attention to court

15. See T. KUHN, THE STRUCTURE OF SCIENTIFIC ReVolutions 92 (2d ed. 1970) (describing scientific revolutions as "non-cumulative developinental episodes in which an older paradigm is replaced in whole or in part by an incoinpatible new one").

16. See, e.g., 1955 ATTORNEY GENERAL's RePort, supra note 12, at 132. For a recent atteinpt to apply a modern version of Spencer's Social Statics, see Maleski, Sociobiology and the California Public Trust Doctrine: The New Synthesis Applied, 25 NAT. Resources J. 429, 436 (1985) (suggesting that the process of legal evolution is a response to ever-changing social conditions).

17. Chapter 647, 26 Stat. 209 (1890) (codified as amended at 15 U.S.C. $\$ \$ 1-7$ (1988)).

18. Northern Pac. R.R. v. Umited States, 356 U.S. 1, 4 (1958); Standard Oil Co. v. Umited States, 221 U.S. 1, 58 (1911); Umited States v. Aluminum Co. of Am., 148 F.2d 416 (2d Cir. 1945). 
doctrine than to statutory language or legislative history. For example, although the statute refers individually to "every contract, combination . . . or conspiracy in restraint of trade," 19 a forest of paper has gone to exegesis of an agglonerative "agreennent" doctrine. Moreover, although the statute prohibits "every" such restraint, court doctrine has limited the statute's application to unreasonable restraints. As a final example, the statute says nothing about "competition," althougl we take that to be the underlying policy. Nonetheless, these slippages seem legitimate enough, given a common law court's admitted function of developing and shaping legal doctrine. In practice, few scholars and no judges have expressed reservations about this common law vision of antitrust. ${ }^{20}$

However, in the midst of this settled view of antitrust as an evolving common law of coinpetition, there remains a nagging difficulty: Given the current consensus that the Supreme Court's adoption of the "rule of reason" in 1911 represents the birth of inodern antitrust law, what do we do with the preceding jurisprudence of "literalism"?21 Do we treat it as the evolutionary precursor to modern antitrust? Or as some pre-rational forebear? There are, of course, numerous possibilities.

Here is the orthodox treatment: Supreme Court doctrine in antitrust's fornative period, 1890-1911, is usually understood as a series of techrical disagreeinents between the "literalist" and "rule of reason" factions. The literalists are portrayed as naifs who took the Sherinan Act at its word-that "every contract, combination ... or conspiracy, in restraint of trade" should be illegal.22 Under this view, the Court finally got it riglit when the "rule of reason" faction secured a majority in two compainion cases-Standard Oil and American Tobacco: Because every agreement to sell something to someone restrains one's ability to sell it to

19. 15 U.S.C. § 1 (1988) (emphasis added).

20. But see, e.g., Arthur, supra note 12 (asserting that antitrust should be viewed as a statutebased legal domain); Spivack, Monopolization Under Sherman Act, Section 2, 50 ANTITRUst L.J. 285 (1982) (accord).

21. For divergent approaches, see 1955 ATTORNEY GENERAI's REPORT, supra note 12; Business Elecs. Corp. v. Sharp Elecs. Corp., 485 U.S. 717, 732 (1988) ("restraint of trade" within the Sherman Act invokes the dynamic potential of the common law, unlimited by the static content assigned to the term in 1890).

Generally, the early cases are read in one of two ways-either as seetion 1 cases that have nothing to do with Standard Oil's section 2 doctrine (which raises a problem with Northern Securities) or as consistent with Standard Oil (that is, the price fixing agreements are always unrcasonable and thus, illegal per se). Justice Taft's opinion, while a circuit court judge, in United States v. Addyston Pipe \& Steel Co., 85 F. 271 (6th Cir. 1898), aff'd as modified, 175 U.S. 211 (1899), however, is cited with some frequency because it is understood as consistent with Standard Oll's rule of reason. For an analysis of the similarities and differences between them, see Peritz, supra note 1, at $313-41$.

22. Sherman Act, § I, 15 U.S.C. § 1 (1988) (emphasis added). 
someone else, all agreements restrain trade. ${ }^{23}$ Thus, only unreasonable restraints should be considered illegal, unless we want to proscribe all commercial agreement. A "literalist" reading of the Sherman Act would render illegal not only price-fixing cartels, but also partnership agreements and even simple contracts for the sale of goods. Certainly, Congress could not have intended such folly. Accordingly, the well-known story concludes, we must apply a "rule of reason" as the framework for analyzing the effects of conduct "in restraint of trade." In short, only unreasonable restraints of trade should raise antitrust concern. ${ }^{24}$

The moral of this familiar story is clear enough-the force of reason restrained the zeal of "hiteralism."25 Certainly, no one can argue with the congressional desire to champion competition in the face of commercial markets overrun by the inerger and cartelization crusades of the late 19th century. But the naive ardor of "literalism" produced a doctrine that proved not only unworkable in practice but also alarming in implication. ${ }^{26}$ Truly productive regulation of coinpetition, the story concludes, deinanded a jurisprudence of reason. A "literalist" reading of the Sherman Act wonld have imposed coinpetition, whatever the costs to society. Accordingly, we moderns have learned to appreciate the "hiterahists" as sincere simpletons whose interpretive inteinperance taught us to recognize the need for reason's rule, a need that they themselves did not understand.

\section{B. A Genealogical View: Property Rights in Restraint of Competition}

A genealogical account of antitrnst's formative period offers a critically different view of the battles between literalists and rule of reasonists and, in so doing, sheds new hight on an old archive of misunderstood records. These records chronicle conflict: They report a series of battles over the relationship between competition policy and common law property rights, battles whose opening nianeuvers are dramatized in congressional debates preceding the Sherman Act's passage in 1890. After

23. See Standard Oil Co. v. United States, 221 U.S. 1, $52-55$ (1911); United States v. American Tobacco Co., 221 U.S. 142 (1911); Chicago Bd. of Trade v. United States 246 U.S. 231 (1918).

24. See, e.g., L. SulLIVAN, HANDBOOK OF THE LAW OF ANTITRUST 181 (1977) (rule of reason allows inquiry only into whether an arrangement significantly decreases conpetition).

25. Addyston Pipe, 85 F. at 271, is an exception. Addyston Pipe is treated as reasonable doctrine because of its direct/ancillary distinction. While we post-realists might not consider it workable, the literalists did. Indeed, it has reappeared in recent court doctrine. See, e.g., Business Elecs. Corp., 485 U.S. at 730 . For an analysis of why this distinction finally proved iradequate to the rule of reasonists, sec Peritz, supra note 1, at 338 (constitutional rhetoric of liberty).

26. See, e.g., Northern Sec. Co. v. United States, 193 U.S. 197, 403 (1904) (Holmes, J., dissenting) (observing that if the purchase of shares in competing companies is a violation because of its potential effect on conpetition, there is hardly any transaction concerning commerce that nuay not be inade a crime). 
President Harrison signed the bill into law, Supreme Court opinions interpreting the Sherman Act disclose a twenty-year war between two factions disputing the relationship between competition policy and common law property rights. When the property rights defenders finally mustered a majority under the "rule of reason" in the Standard Oil opinion, new struggles erupted im the halls of Congress-this time culminating in the passage of the Clayton and Federal Trade Commission Acts of 1914.27 As we all know, both statutes deploy the rhetoric of competition.

Unlike the orthodox view of the formative years, this counter-history is not a narrative account of the evolving common law of antitrust. Rather, it is a correspondence of struggles between factions holding two radically opposed views of competition policy. ${ }^{28}$

This narrative begins on January 21, 1888, early in the first session of the 50th Congress, with Representative Henry Bacon's (D. N.Y.) introduction of a resolution directing the House Committee on Manufactures to investigate trusts in several industries and to recommend suitable legislation. ${ }^{29}$ In the midst of this mvestigation, both the Democratic and Republican parties adopted antitrust platform planks. On July 30 , the House Committee on Manufactures issued an interim report. ${ }^{30}$ Within two weeks, Senators John H. Reagan (D. Tex.) and John Sherman (R. Ohio) imtroduced antitrust bills. Both were referred to the Senate Finance Committee, whose chairman was Senator Sherman. ${ }^{31}$ (Senator Sherman's home state of Ohio had been the domicile of John D. Rockefeller's Standard Oil Trust.) Almost a month later, the Finance Committee reported to the full Senate the Sherman bill, with the following operative langnage: "That all arrangements, contracts, agreements, trusts, or combinations ... made with a view, or which tend to prevent full and free competition ... or which tend to advance the cost to the consumer ... are hereby declared to be against public pohicy, unlawful, and void." 32 Floor debate on this bill began on January 23,1889 , in the Senate's second session.

27. Federal Trade Commission Act, Pub. L. No. 63-717, ch. 311, 38 Stat. 717 (1914) (codified as amended at 15 U.S.C. $\S \S 41-77$ (1988)); Clayton Act, Pub. L. No. 63-212, ch. 323, 38 Stat. 730 (1914) (codified as amended at 15 U.S.C. $\S \S 12-27$ (1988)).

28. Note that I did not characterize this as an eternal return of the same conflict.

29. H.R. Misc. Doc. No. 124, 50th Cong., 1st Sess., 19 CoNG. REc. 719 (1888) (in substitution of H.R. REP. No. 67, introduced by Representative William E. Mason (R. Ill.)). The resolution directed the House Judiciary Committee to investigate certain charges about trusts' high prices to consumers. 1 E. KINTNER, THE LEgISLATIVE HistoRy OF THE FEDERAL ANTITRUST LAWS AND RELATEd STATUTES 53 (1978).

30. S. 3440 and S. 3445 , SOth Cong., 1st Sess., 19 CoNG. REc. 7512 (1888).

31. 1 E. KINTNER, supra note 29 , at 38.

32. S. 3445, SOth Cong., 2d Sess., 20 CoNG. REc. 1120 (1889) (as amended). 
After fifteen months of consideration and sometimes heated exchange, the full Senate by a roll-call vote of 31-28 accepted a motion to refer Senator Sherman's bill to committee-this time to the Committee on the Judiciary. ${ }^{33}$ Only six days after the bill's referral, Committee Chairman George F. Edmimds (R. Vt.) reported a substitute bill that looked nothing like its predecessor. In place of Senator Sherman's 1888 language of "full and free competition" and "cost to the consumer," the 1890 bill substituted "contract . . . in restraint of trade" and "monopolize, or attempt to monopolize ... trade."34 Six days later, the 1890 bill passed by a roll-call vote of 52-1.35 Despite drastic differences in statutory language and limited debate over the 1890 bill, we now take for granted that there are, or should be, no significant differences between the two versions. We assume that antitrust policy is properly founded in free competition and its connection to consumer prices, even though the language referring to these pohicies was jettisoned. Neither history nor logic compels this view.

Indeed, Senator Sherman expressed opposition to the substitute bill. He stated that the substitute would be,

totally ineffective in dealing with combinations and Trusts. All corporations can ride through it or over it without fear of punishment or detection. It is manifest that if any rehef is to be had it must be as a result of popular opinion or by the action of the House, where amendments may be provided which will restore in substance the original design of the bill. ${ }^{36}$

Why was Senator Sherman so adainantly opposed to the new bill? To restate the question, what significance can be attributed to the substitution of the familiar common law language of "restraint of trade" and "monopolization" for the rhetoric of "full and free competition" and "advancing the cost to the consumer"? A fresh look at the congressional debates provides a persuasive answer.

Reflecting the spht vote that committed Senator Sherman's bill to Senator Edmnnds' Committee on the Judiciary, floor debate was split into two rhetorical cainps. ${ }^{37}$ Senator Slierman and other supporters of the original bill's language of "full and free competition" made frequent reference to "the industrial hiberty of citizens," which included not only "the interest of the consumer" but also "the riglit of every man to work,

33. 21 CoNG. REC. 2731 (1890) (Sen. Walthall's (D. Miss.) motion).

34. S.1, 51st Cong., 1st Sess., 21 CoNG. REc. 2901 (1890).

35. 21 CoNG. REC. 3152-53 (1890). After several days of deliberation on the Conference Reports, the Bill was passed. See Peritz, supra note 1, at 303 n.88.

36. Mr. Sherman Gives $U_{p}$ Hope, N.Y. Times, Apr. 8, 1890, at 4, col. 4, (reporting comments appearing in the St. Louis Globe-Democrat), reprinted in 1 E. KINTNER, supra note 29, at 24 n.1, 153.

37. For an extended study of the debates, see Peritz, supra note 1, at 291-313. 
labor, and produce in any lawful vocation." 38 They denounced "coinbinations of capital" that "inake competition impossible." 39 In contrast to today's overdetermined focus on consumers, their notion of industrial liberty mcluded a sense of the public as both competitors and employees of the new large combinations of capital, whose power rendered "the boasted hiberty of the citizen . . . a myth."40 These concerns for consumer and producer hiberty also implicated pohitical liberty. In short, Senator Sherman and his allies believed that industrial liberty was the victim of private agreements between competitors, agreements such as trusts and cartels. Industrial liberty was seen as a product of competitive markets populated by numerous and roughly equal rivals.

But there was another side to the debates, another kind of concern expressed about competition. In this rhetorical cainp were those persons who believed that competition could sometimes be as dangerous as combimations. They behieved that agreements to mitigate the effects of competition were sometimes justifiable. The following statement by Senator Orville H. Platt (R. Coim.) in the debate just prior to the original bill's referral to the Committee on the Judiciary captures this position:

The true theory of this matter is that prices should be just and reasonable and fair, that prices... should be such as will render a fair return to all persons engaged in its production, a fair profit on capital, on labor, and on everything else that enters into its production. . . . [E]very man in business ... has a right, a legal and a inoral right, to obtain a fair profit upon his business and his work; and if he is driven by fierce competition to a spot where his business is unremunerative, I beheve it is his right to combine for the purpose of raising prices until they shall be fair and remunerative. ${ }^{41}$

In contrast to the view expressed by Senator Sherman, Senator Platt (and his allies) beheved that industrial liberty required the freedom to enter into contracts to coinbat the effects of brutal competition. As Representative Stewart (R. Vt.) later said in the House debates, "It is just as necessary to restrict competition as it is to restrict combination." "42

Congress's last-minute turn to the cominon law language of "inonopolization" and "restraints of trade" was a reaction against the original bill's exphcit and unmediated imposition of "full and free competition" as the ouly natural and legitimate form of cominerce. The bill, as passed, used familiar language that carried with it stable images drawn froin a cominon law tradition grounded in freedoin of contract

38. 21 CONG. REC. 2457 (1890).

39. Id. (Sen. Sherman); id. at 1768 (Sen. George (D. Miss.)).

40. Id. at 2561 (Sen. Teller (R. Colo.)).

41. 21 CONG. REC. 2729-30 (1890).

42. 21 Cong. Rec. 5956 (1890) (discussing First Conference Report, 51st Cong., 1ST SESS.). 
principles and private property rights, including the right to a "fair profit." 43

Thus, when Justice Holmes wrote some fifteen years later that the Sherinan Act "says nothing about competition," 44 he not only was teaching his hiteralist brethren a lesson about the art of hiteralism; he also was taking the rule of reasonists' side in the formative era's penultimate Court battle to capture the normative ground of antitrust law. Seven years later, the rule of reasonists emerged triumphant in the era's last suprenie judicial conflict over the relationship between competition policy and common law property rights, when they announced the Standard Oil and American Tobacco opinions. Disagreement over the meaning of competition pohicy would no longer take the form of hiteralist against rule of reasonist.

But in the two decades preceding Standard Oil, these two factions fought numerous battles over treatment of open price-fixing cartels and secret bid-rigging schemes. In cases like Trans-Missouri Freight Association, price-fixers and rule of reasonist dissenters agreed that the "plain intention of the law was to protect the hiberty of contract and the freedom of trade." 45 If the government intervened to stop parties from entering into a reasonable contract to forestall ruinous competition, they claimed, then unreasonable prices would be the consequence. Unhealthy competition and unreasonable prices would prevail due to the illegitimate exercise of judicial authority. ${ }^{46}$ Echoing congressional speeches about fair price, Justice White's dissents developed a "rule of reason" to argue for the right to fix fair prices to protect a fair return on one's property. ${ }^{47}$ But for twenty years, the hiterahists prevailed. Justice Peckham, in contrast, made it clear that all price fixing agreements were illegal, regardless of the reasonableness of the prices fixed: "Competition ... is a necessity for ... securing in the end just and proper rates."48 In short, competition was seen as the only legitimate arbiter of fair price.

Even if consumers benefit from lower prices, Justice Peckham concluded for the hiteralist majority, private agreements in restraint of trade would drive "out of business the sniall dealers and worthy men whose hives have been spent therein." 49 Firms of relatively sinall size (and

43. For an extended analysis of this point, see Peritz, supra note 1, at 303-13.

44. Northern Sec. Co. v. United States, 193 U.S. 197, 403 (1904) (Holmes, J., dissenting).

45. United States v. Trans-Missouri Freight Ass'n, 166 U.S. 290, 355 (1897) (White, J., dissenting).

46. Id.

47. See Peritz, supra note 6, at 516-27.

48. Trans-Missouri Freight, 166 U.S. at 333.

49. Id. at 323. 
roughly equal) are at the core of the literalist view of industrial liberty, since,

it is not for the real prosperity of any country that such changes should occur which result in transferring an independent business man, the head of his establishment, small though it might be, into a mere servant or agent of a corporation for selling the commodities which he once manufactured or dealt $m$, having no voice in shaping the business policy of the company and bound to obey orders issued by others. ${ }^{50}$

The literalists believed that Congress was concerned witl nuaintaining a viable middle class of independent entrepreneurs.

The rule of reason faction disagreed. Justice White insisted tliat the "utnost liberty of contracting" was necessary to avert a state of industrial warfare. ${ }^{51}$ To justify a railroad cartel's riglit to fix (reasonable) prices, Justice White referred to the Court's earlier affirmation of a union strikebreaking injunction in tlie infamous Pullman Coinpany case-In re Debs. ${ }^{52}$ In that case, according to the rule of reasonists, the trial court's literalist interpretation of the Sherman Act in enjoming the striking union inade tlie Act "einbrace every peaceable orgainzation or conbination of the laborer to benefit his condition eitler by obtaining an increase of wages or diminution of the lours of labor."53 Putting the railroad capitalists in the position of union wage labor, Justice White suggested that conbination was appropriate not only to equalize bargaining power in labor's struggle to win a fair wage froin capital, but also to elininate conipetition between railroads in their efforts to salvage a "fair profit" froin their invested capital. For Justice White, coinbination was the only civilized alternative to industrial warfare between capitalists-and well wortl the price of entrepreneurial independence. For Justice Peckhan, the Sherman Act reflected a congressional policy endorsing conipetition, which legitimized the commercial harm of less-than-fair profits.

But when Standard Oil announced the "rule of reason" in 1911, not even Justice Peckham counted himself among the literalists. Joining in tlie new inajority's rlietoric of property riglits, Justice Peckhanı apparently agreed that the "rule of reason" was necessary "to prevent [the Slierman Act] fron destroying all liberty of contract and all substantial right to trade, and thus causing the act to be at war with itself by annihi-

50. Id. at 324.

51. Id. at $355-56$.

52. 158 U.S. 564 (1895).

53. Trans-Missouri Freight, 166 U.S. at 356. It is interesting to note that Justice White's concern for labor's right to organize did not lead him to dissent from Justice Peckham's literalist opinion for a unanimous court in Debs. Apparently, the analogy between capitalists and labor was only a debating point. Justice White dissented to support the former's right to combine, but not the latter's. He voted with a unanimous court to enjoin the union strikes in Debs. 
lating the fundamental right of freedoin to trade." 54 . What might have convinced Justice Peckham to defect to the rule of reasonist camp?

The answer hes in a merger case seven years earlier that already had splintered the Court's literalist majority. Northern Securities Co. v. United States produced four opinions, including two dissents calling for the "rule of reason." Justice Peckham joined in both dissents. The issue of individual property rights, although already addressed in the earlier cartel cases, reappeared in the merger context but with coinpelling force because, very simply, inerger cases involve the legality of buying and selling businesses. For Justice Peckham (and for us moderns), such agreements enibody the clearest exercise of property rights-freedoin of contract. If property rights and freedom of contract protect anything at all, they protect the right to sell one's property, one's business. The conflict between property rights and coinpetition policy, between liberty of contract and equality among rivals, could not be ignored in Northern Securities because the merger involved two competing railroads with over 9000 miles of parallel track. Certainly this merger restramed trade. If the Sherman Act were apphied literally to this neerger and to all mergers, then the statute would prevail over the fundamental property right to sell one's business. As Justice White wrote, "[T]he primciple that the ownership of property is embraced within the power of Congress to regulate commerce, whenever that body deems that a particular character of ownership ... may restrain commerce . . . is in my opinion, in conflict with the most elementary conceptions of riglits of property." 55 This sort of logic converted Justice Peckhain into a disciple of the "rule of reason."

54. United States v. American Tobacco Co., 221 U.S. 142, 180 (1911) (Justice Peckham sided with Justice White's majority opinion).

55. Northern Sec. Co. v. United States, 193 U.S. 197, 370 (1904) (White, J., dissenting). For a full analysis of this point and the importance of the common law distinction between direct and ancillary restraints, first developed in then Circuit Judge Taft's United States v. Addyston Pipe \& Steel Co., 85 F. 271 (6th Cir. 1898), aff'd as modified, 175 U.S. 211 (1899), opinion and recently revived in Justice Scalia's Business Elecs. Corp. v. Sharp Elecs. Corp., 485 U.S. 717, 732 (1988), opinion, see Peritz, supra note 1, at 313-24; Peritz, supra note 6, at 549-54. Justice Peckham's participation in this "rule of reason" dissent also suggests a "logical" link to his earlier competitionbased literalisn. In his earlier opinions, Peckham articulated a notion of industrial liberty consonant with his reading of "liberty" as used in the fourteenth amendment: In Allgeyer v. Louisiana, 165 U.S. 578 (1897), he had already characterized it as the "hiberty of the citizen to pursue any livelihood or vocation, and for that purpose to enter into all contracts which might be proper, necessary and essential to carrying out those objects to a successful conclusion." United States v. Joint Traffic Ass'n, 171 U.S. 505,571 (1898) (Justice Peckham described his holding in Allgeyer). Peckham's turn from competition to property logic can also be understood as his continuing commitment to individual liberty: In price-fixing cases, the liberty to conduct one's business inust be protected. In merger cases, the liberty to sell one's business merits the same seeurity. Though these two freedoins appear to confict when viewed in terms of competition and property logics, they do seein to correspond to Peckham's comınitment to individual liberty. 
This property rhetoric later attracted the new majority for the Standard Oil opinion's formal announcement of the "rule of reason" in 1911. But in the federal and state legislatures, there was swift and widespread reaction against the Court's new eategory of reasonable trusts, even though the Standard Oil Trust was found unreasonable and thus illegal. The groundswell of activity imcluded passage of antitrust provisions in twenty states as well as congressional hearings on antitrust legislation. These hearings resulted in two new statutes, both written in the rhetoric of competition. (Justice Holmes could no longer proclaim that the antitrust laws said nothing about competition.) Although different in design, both the Clayton and Federal Trade Commission Acts of 1914 said something about competition. The Clayton Act proscribed a series of practices, including mergers, whose effects "may be to substantially lessen competition." 56 The statute's legislative history clearly reflected a desire to proscribe inergers (and the other listed practices) in their incipiency ${ }^{57}$ - that is, before they substantially lessened competition. Moreover, the Federal Trade Commission (FTC) was established to investigate and enjoin "unfair methods of competition," that is, to regulate competition. ${ }^{58}$

As we have seen, Congress responded to the Court's shift to a "rule of reason" by making explicit its commitment to competition policy. Given the Court's concern for the protection of property rights, the stage was reset for further attempts to work out the tensions between competition policy and common law property rights, between commitments to liberty and equality. Would the "rule of reason," a Sherman Act doctrime, be applied to the new statutes? Or might the Court take the new statutes as an expression of congressional rejection of the "rule of reason"? Would they siniply be treated as separate statutes? Whatever jurisprudential course the Court would follow, at the very least, the tension between property rights and competition policy was recharged.

56. 15 U.S.C. $\S 13($ a) (1988).

57. Here is how the Senate described the purpose of the Clayton Act:

Broadly stated, the bill, in its treatment of unlawful restraints and monopolies, seeks to prohibit and make unlawful certain trade practices which, as a rule, singly and in themselves, are not covered by [the Sherman Act], or other existing antitrust acts, and thus, by making these practices illegal, to arrest the creation of trusts, conspiracies, and monopolies in their incipiency and before consummation .... .

S. Rep. No. 698, 63d Cong., 2d Sess. 1 (1914), quoted in United States v. E. I. du Pont de Nemours \& Co., 353 U.S. 586, 597 (1956).

58. 15 U.S.C. $\S 45(a)(2)(1988)$. 


\section{Second Disagreement About Competition as Constituting Antitrust's Middle Period: The Rule OF REASON}

According to the orthodox view, antitrust's formative period ended with the Standard Oil opinion's announcement of the "rule of reason." With the technical question of hiteralism resolved, the Court could then turn to the meaningful problem of determining the competitive effects of conduct falling under the antitrust laws. On balance, does the conduct under scrutiny regulate competition? Or does it restrain competition? The middle period began with the sensible recognition of a technical need for a "rule of reason." But it ended in normative chaos, with the "rule of reason" out of control. The balancing of competitive effects grew to mean too many different things to too many people. The "rule of reason" exploded to constitutional proportions.

Viewed from a genealogical perspective, the Court's adoption of a "rule of reason" resolved nothing. Not only did the underlying tension between competition policy and common law property rights contimue to produce antitrust doctrine, but the congressional enactments of 1914 sought to make explicit the primary importance of competition policy. During the Great Depression years, the first "fair-trade" Act, ${ }^{59}$ which permitted resale price inaintenance in states with enabling statutes, called into question the primacy of competition policy. Court doctrine oscillated, too, between a "rule of reason" standard and per se illegality, with occasional swings into per se legality. In short, no era had ended. Nor liad another begun. The issues remained: What values constituted competition policy and property rights? ${ }^{20}$ What Court doctrines and statutes did these tensions produce? When one rhetoric dominated, did that domination tilt decisions or statutes in favor of one class-large producers or small, for example? Or were the imphications indeterminable?

\section{A. The Orthodox View: Balancing Competitive Effects}

Antitrust's middle period began with the Standard Oil opinion's pronounceinent of the "rule of reason." But it is Justice Brandeis' opin-

59. Miller-Tydings Resale Price Maintenance Act of 1937, ch. 690, 50 Stat. 693; later extended by the McGuire Resale Price Maintenance Act of 1952, ch. 745, 66 Stat. 631, repealed by the Consumer Goods Pricing Act of 1975, 89 Stat. 801.

60. Although I have mentioned them only in passing, the tensions between liberty and equality raise equally difficult questions about the internal dynamics of both competition policy and property rights. These will be highlighted in some of the analysis that follows. See infra notes 155-77 and accompanying text. 
ion in Chicago Board of Trade v. United States that we renember for the rule's inost eloquent restatement:

[T] he legality of an agreement or regulation cannot be determined by so simple a test, as whether it restrains competition. Every agreement concerning trade, every regulation of trade, restrains. To bind, to restrain, is of their very essence. The true test of legality is whether the restraint imposed is such as merely regulates and perhaps thereby promotes competition or whether it is such as may suppress or even destroy competition. To determine that question the court must ordinarily consider the facts peculiar to the business to which the restraint is apphed; its condition before and after the restraint was imposed; the nature of the restraint and its effect, actual or probable. The history of the restraint, the evil believed to exist, the reason for adopting the particular remedy, the purpose or end sought to be attained, are all relevant facts. ${ }^{61}$

The restraint at issue was the Chicago Board's "Call" Rule, which required inembers doing business in one category-grain to arrive in the period between the session's close and its opening the next business day-to conduct such business only at the Board's closing price. Government attorneys characterized this requirement as simple price-fixing. Board attorneys argued that the Rule's purpose was "not to prevent coinpetition or to control prices, but to proinote the convenience of members by restricting their hours of business and to break up a inonopoly in that branch of the grain trade acquired by four or five warehousemen in Chicago."62 The Court agreed with the Board's view, concluding that the Rule's regulation of busmess hours "helped to improve market conditions." 63

In assessing competitive effects under the "rnle of reason," the Court considered something as far afield as a tendency "to shorten the working day or, at least, limit the period of most exacting activity."64 Were there any limits to this "rule of reason" analysis? In theory, perhaps not. But in practice, the Court's balancing jurisprudence was limited to a small number of counterweights. Indeed, during antitrust's middle period, the Court most commonly evaluated only four competitive effects under the "rule of reason"-competitive effects that are referred to throughout antitrust discourse.

First of all, there has been widespread concern about the process of competition-about unfair methods of competition. This attention to process has not been confined to the FTC Act's language of "unfair
61. Chicago Bd. of Trade v. United States, 246 U.S. 231, 238 (1917).
62. Id. at 237.
63. Id. at 240 .
64. Id. at 241. 
methods of competition" and associated rules and opinions. ${ }^{65}$ In the context of merger doctrine in section 7 of the Clayton Act, the Court has interpreted congressional policy regarding vertical integration as founded in a desire to prevent such mergers when they "deprive ... rivals of a fair opportunity to compete."66 As an element of predatory pricing doctrine under section 2 of the Sherman Act, the Court requires evidence of predatory intent, which traditionally has included proof of unfair methods of competition such as industrial spying. ${ }^{67}$ As a final example, even in the hard-core section 1 offense of horizontal price-fixing, the Court found that a joint selling agency among 170 coal producers was justified, in significant part, by the defendants' "honest effort to remove abuses, to make coinpetition fairer, and thus to promote the essential interests of commerce."68 This attention to fair process inakes good sense, given the likelihood that inarket participants must be persuaded of the systein's fairness and legitimacy. ${ }^{69}$

Second, we are all familiar with the importance attached to wealth transfers that can result from anti-competitive practices, at least insofar as the wealth is transferred from consuniers. Whether wealth is extracted by a single-firm monopoly, or multi-firm oligopohes or cartels, both the Court and Congress have considered competition policy a means of controlling monopoly pricing. In his landmark study of antitrust legislation, Robert Lande lias argued forcefully that wealth transfers constituted Congress' original and primary concern. ${ }^{70}$ Although this is an overstate-

65. 15 U.S.C. $\S 45(a)(1)$ (1988).

66. Brown Shoe Co. v. United States, 370 U.S. 294, 324 (1961) (citing H. R. REP. No. 1191, 81 st Cong., 1st Sess. 8 (legislative history of 1950 Celler-Kefauver Amendnient to the Clayton Act)); see also E.I. du Pont Co. de Nenours \& Co. v. United States, 353 U.S. 586 (1957) (nnfairness of buying stock in General Motors for the alleged purpose of becoming its major snpplier of certain paints and fabrics).

67. See, e.g., Utah Pie Co. v. Continental Baking Co., 386 U.S. 685 (1967) (proof of predatory intent required to prove violation of Clayton Act). The Court has not spoken to this issue in recent years. Since Areeda \& Turner's influential article, Predatory Pricing and Related Practices Under Section 2 of the Sherman Act, 88 HARV. L. REv. 697 (1975) (looking to "the relationship between a firm's prices and its costs in order to define a rational dividing line between legitimately competitive prices and prices that are properly regarded a predatory"), only the Fifth and Ninth Circuits have allowed evidence other than cost/price data. See, e.g., International Air Indus., Inc. v. America Excelsior Co., 517 F.2d 714 (5th Cir. 1975), cert. denied, 424 U.S. 943 (1976); William Inglis \& Sons Baking Co. v. ITT Continental Baking Co., 668 F.2d 1014 (9th Cir. 1981), cert. denied, 459 U.S. 825 (1982). For a thoughtful analysis, see Circuit Judge Breyer's opinion in Barry Wright Corp. v. ITT Grinnell Corp., 724 F.2d 227 (1st Cir. 1983).

68. Appalachian Coals, Inc. v. United States, 288 U.S. 344, 372 (1932). This is not, of course, the only example of section 1 price fixing that has been judged according to the rule of reason. For further discussion, see infra text accompanying notes 101-29.

69. See, e.g., North, Structure and Performance: The Task of Economic History, 16 J. Econ. LITERATURE 963, 975-76 (1978). Those with the market opportunity and inclination to act unfairly inight disagree.

70. Lande, supra note 4 , at $150-51$. 
ment of congressional intent, the Court consistently has expressed concern about consumers. For example, even if a cartel price is "reasonable," the danger of higher prices, of future wealth transfers, is sufficiently important to support a cartel's dissolution:

The power to fix prices, whether reasonably exercised or not, involves power to control the market and to fix arbitrary and unreasonable prices. The reasonable price fixed today may through economic and business changes become the unreasonable price of tomorrow. ${ }^{71}$

In the context of monopolization under section 2 of the Sherman Act, an analogous concern with predatory (low) prices arises froin the belief that the motivation for driving competitors out of business is the resulting power to charge inonopoly prices.

Third, coinpetition has long been associated with efficiencies of different varieties-even before Robert Bork's implausible and inaccurate account of the Sherman Act's passage as an ode to Herbert Spencer's Social Statics.72 For example, the Court was amenable to an efficiency argument almost sixty years ago, when a group of 170 independent coal producers charged with forming a joint selling agency to fix prices responded that they organized the Appalachian Coal Company "for the purpose of proinoting efficiency and econoiny."73 More recently, the Court has allowed relatively sinall and strugghing inanufacturers to reorganize their distribution and dealer networks in order to coinpete more efficiently with established manufacturers, even when such efforts restram intra-brand coinpetition. ${ }^{74}$ Although there are serious questions

71. Umited States.v. Socony-Vacuum Oil Co., 310 U.S. 150, 213 (1939). This opinion is recognized as the most extreme statement of what once was the rule that horizontal price-fixing is illegal per se. For an insightful analysis of the current state of per se illegality in the rule of reason paradigm, see Krattenmaker, Per se Violations in Antitrust Law: Confusing Offenses with Defenses, 77 GEO. L.J. 165 (1988).

72. R. BORK, ANTITRUST PARADOX 66-69 (1978). Too much effort has already been expended in demonstrating that Bork's account is mistaken. For a painstaking point-by-point demolition of Bork's thesis, see Flynn, The Reagan Administration's Antitrust Policy, "Original Intent" and the Legislative History of the Sherman Act, 33 ANTITRUST Bull. 259 (1988). See also Peritz, supra note 1, at 289-90 \& n.22. Although I do not recall Bork making an explicit reference to Spencer, the neoclassical view of laissez-faire expounded by Bork is grounded in the Social Darwinian (and sociobiological) simplifieation that the best win and that it is best that they do. My reference to Spencer is an allusion to Justice Holmes's well-known dissenting opinion in Lochner v. New York, 198 U.S. 45, 74 (1905) ("The fourteentli amendment does not enact Mr. Herbert Spencer's Social Statics.").

73. Appalachian Coals, Inc. v. United States, 288 U.S. 344, 346 (1932).

74. The watersled case was White Motor Co. v. United States, 372 U.S. 253 (1963) (affirming grant of summary judgment against appellant, a small truck manufacturer who had engaged in franclise contracts restricting dealers, noting that sucli agreements may be within the "rule of reason"). For an opinion written after the middle period, see Continental T.V., Inc. v. GTE Sylvania Inc., 433 U.S. 36 (1977) (holding that respondent television manufacturer's vertical restrictions on franclises were not per se violations of the Sherman Act and should be evaluated under the rule of reason). 
about the nature of the relationship between competition and efficiency, everyone assumes that the two are related. ${ }^{75}$

Finally, we have been attracted not only by the virtues of competition as a political economy, as a mechanism for controlling not only economic power, but also by the social and pohtical influence associated with economic power. Judge Learned Hand's well-known Second Circuit opinion in United States v. Aluminum Company of America, written while sitting as the higliest Court by special designation, ${ }^{76}$ stated that one of the purposes of section 2 of the Sherman Act (which proscribes inonopolization) "was to perpetuate and preserve, for its own sake and in spite of possible cost, an organization of industry in sinall urnits which can effectively coinpete with each other."'77 In the massive Brown Shoe case, involving botll horizontal and vertical merger doctrime under section 7 of the Clayton Act, Chief Justice Warren wrote:

[W] cannot fail to recognize Congress' desire to promote competition through the protection of viable, sinall, locally owned businesses. Congress appreciated that occasional higher costs and prices might result froin the inaintenance of fragmented industries and markets. It resolved these coinpeting considerations in favor of decentralization. ${ }^{78}$

Of course, it has not been established that sinaller business units result in higher costs, even in heavy industry. In fact, einpirical researcli over the last fifty years has shown that sinaller business units tend to be more efficient. ${ }^{79}$ But whatever the relationship between firm size and efficient

75. See Peritz, supra note 1, at 289 n.20; Peritz, supra note 6, at 554-76 (analyzing free rider doctrine as founded in notion of efficient distribution); Peritz, supra note 3, at 1279-82 (explicating efficiency logics found in Posner's writings about price discrimination).

76. 148 F.2d 416, 421 (2d Cir. 1945). The Second Circuit panel lieard this appeal after four members of the Supreme Court had conflicts of interest; the matter was referred to the circuit court under the 1944 amendment to 15 U.S.C. \$ 29. See Act to Amend the Expediting Act, cli. 239, 58 Stat. 272 (1944), repealed by Judicial Code and Judiciary Act, cl. 646, 62 Stat. 869, 989 (1948).

77. ALCOA, 148 F.2d at 429; see also Rostow, The New Sherman Act: A Positive Instrument of Progress, 14 U. ChI. L. REv. 567, 577-80 (1947) (discussing Judge Hand's ruling in the $A L C O A$ case).

78. Brown Slıce Co. v. Umited States, 370 U.S. 294, 344 (1962) (discussing legislative history of Celler-Kefauver Amendment to section 7 of the Clayton Act). Senator Kefauver stated in floor debates:

I think that we are approaching a point where a fundamental decision must be made in regard to this problem of economic concentration. Shall we permit the economy of the country to gravitate into the liands of a few corporations ... ? Or on the other liand are we going to preserve sinall busimess, local operations, and free enterprise?

96 CoNG. REC. 16,450 (1950), quoted in Umited States v. Von's Grocery Co., 384 U.S. 270,276 n. 10 (1966).

79. See Adams \& Brock, Reaganomics and the Transmogrification of Merger Policy, 33 ANTITRUST BULL. 309, 338-46 (1988) [heremafter Adams \& Brock, Reaganomics] (arguing that inerger induced giant busimesses do not benefit from enhanced performance); Rostow, supra note 77, at 568 \& n.3; Slieplierd, Three "Efficiency School" Hypotheses About Market Power, 33 ANTITRUST BuLL. 395, 395-410 (1988) (criticizing the Chicago "efficiency school" liypotliesis that inonopolies are more efficient). See also Federal Trade Commission, Relative Efficiency of Large, Medium- 
operation, a special solicitude for small business lias been an important implication of competition policy. ${ }^{80}$

The Court's balancing of these various competitive effects soon blossomed into a rlietoric of constitutional dimension. The Slierman Act was described as a "comprehensive cliarter of economic liberty aimed at preserving free and unfettered competition as the rule of trade."81 Cliief Justice Huglies wrote: "As a charter of freedom, the Act has a generality and adaptability coinparable to tliat found to be desirable in constitutional provisions. . . I Its general phrases, interpreted to attain its fundamental objects, set up the essential standard of reasonableness." 82

But while tlie Court was balancing competitive effects under a constitution-like "rule of reason," scliolars and some practitioners criticized the jurisprudence as vague, as too flexible. They called for clarity, for constraints. In the still well-respected Report of the Attorney General's Committee to Study Antitrust Laws, a group of private practitioners, government attorneys, and scliolars expressed "a modern view of the Sherman Act [tliat] can start witl Standard Oil Co. of New Jersey v. United States." 83 What was modern about the panel's view was its claim that "witl its Rule of Reason to translate into law eacli advance in econormic teaching, the Act lias kept abreast of the times." 84 In short, the rule of reason was recliaracterized as tlie economic idea of "workable competition." 85 Within a few years, Professors Kaysen and Turner published

SIZED, AND SMALl Business 12-14 (TNEC Monograph No. 13, 1941) (finding large size most efficient in $11 \%$ of total test, medium size in 55\%, and sinall size in 34\%); Adams \& Brock, The "New Learning" and the Euthanasia of Antitrust, 74 CAL. L. REv. 1520, 1546-64 (1986) (presenting empirical refutation of the "mythology of bigness," that is, the presumed relationship between bigness and operating efficiency, mcluding the Schumperterian view that technological advancennent calls for dominant firms); Scherer, Book Review, 86 YALE L.J. 974, 986-88 (1977) [hereinafter Scherer, Review] (review of R. POSNER, ANTITRUst LAw: AN ECONOMiC PERSPECTIVE (1976)) (arguing that the goals of efficiency and preservation of small business are not contradictory). Cf. Federal Trade Commission Staff Report, Conglomerate Merger Performance: AN EMPIRICAL ANALYSIS OF NINE CORPORATIONS 33-60 (1972) (finding sizable mergers followed by insignificant operational changes directed at improving efficiency); D. RAVENSCROFT \& F. SChERER, MERGERS, SEll-OFFS, AND ECONOMIC EFFiciency 212, 224 (1987) (finding that productivity and efficiency losses accompany the average merger); F. SCHERER, A. BECKENSTEIN, E. KaUfer \& R. MURPhy, The ECONOMICS OF MULTI-PLANT OPERATION-AN INTERNATIONAL COMPARISIONS STUDY 237-354 (1975) (finding that large mergers result in minimal efficiency benefits); Mueller, Mergers and Market Share, 67 REV. EcoN. \& STAT. 259, 266 (1985) (finding no support for hypothesis that mergers improve efficiency).

80. For evidence of this strain of Jeffersomian entrepreneurialism in vertical restraints context, see Peritz, supra note 6, at 567-74 (discussing White Motor Co. v. Umited States, 372 U.S. 253 (1963) and Continental TV, Inc. v. GTE Sylvamia Inc., 733 U.S. 36 (1977)).

81. Northern Pac. Ry. v. Umited States, 356 U.S. 1, 4 (1958).

82. Appalachian Coals v. United States, 288 U.S. 344, 359-60 (1933).

83. 1955 ATTORNEY GENERAL REPORT, supra note 12, at 5.

84. Id. at 132. For an extended analysis, see Peritz, supra note 3, at 1223-31.

85. 1955 ATTORNEY GENERAL's REPORT, supra note 12, at 132. 
their concise and influential treatise on antitrust and economics, which also called into question the value of non-"economic" pohicies. ${ }^{86}$

The middle period, the era of constitutional antitrust, began to crumble with the publication, first in Fortune magazine and then in the Columbia Law Review, of "The Goals of Antitrust: A Dialogue on Policy." In that debate, Robert Bork and Ward Bowman argued that efficiency should constitute antitrust's only social goal. If we continue to disagree about the implications of competition, they claimed, antitrust would "remain" hopelessly at war with itself. 87 They concluded that the "rule of reason" could mean only the logic of neo-classical economics.

\section{B. A Genealogical View: Balancing Property Rights and Competition Policy}

This counter-history of antitrust's umiddle period does not dispute claims of the incoherence and unworkability of "rule of reason" jurisprudence. Rather, it challenges the orthodox view of the underlying problem, the behief that the instability of the middle period's constitution-like jurisprudence derived from a fundamental disagreement about the legitiinate implications of coinpetition policy. I subimit that we caimot make sense of antitrust law until we remember that the disagreement involved inore than coinpetition. We can take two steps to supplement our traditional analysis. First, we can think of competition rhetoric as the set of arguments produced by an internal tension between commitments to liberty and equality. Second, we can think of competition as one rhetorical pattern in tension with another network of arguments associated with common law property rights. Property rhetoric is coinplex, too, on account of its own internal tension between liberty and equality. In short, competition rhetoric reproduces only one eleinent of a inore considerable disagreement underlying antitrust law during the middle period.

To sketch the contours of a counter-history, to provide an account of the more considerable disagreement, attention will be focused on examplcs of price-fixing doctrine that fall into three familiar categories. These three categories are per se legality, "rule of reason" balancing, and

86. C. KAYSEN \& D. TURNER, ANTITRUST POLICY: AN ECONOMIC AND LEGAL ANALYSIS (1959). Compare Kaysen, The Corporation: How Much Power? What Scope?, in The CoRPORATION IN MODERN SOCIETY 85-105 (E. Mason ed. 1960) (describing socio-economic foundations of corporations' social and political power).

87. See Bork \& Bowman, The Crisis in Antitrust, ForTune, Dec. 1963, at 138; The Goals of Antitrust: A Dialogue on Policy, 65 CoLUM. L. REV. 363 (1965) (symposium, consisting of a critique of antitrust policy by Robert Bork and Ward Bowman, then at Yale; a defense of antitrust policy by Harlan Blake and William Jones, then at Columbia; and rebuttals). For an extended critique of the Chicago School's claims, within the doctrinal context of price discrimination, see Peritz, supra note 3 , at 1231-92. 
per se illegality. Think of eacli category as produced by conflicts between competition policy and common law property rights. If a practice is illegal per se, then the text's rlietoric might reflect competition policy's temporary advantage over property riglits. When the "rule of reason" standard is apphed, the tension might exhibit a moment of rhetorical equipoise. If a practice is seen as legal per se, the text might reflect an eplemeral triumpli of property rights. Imagine each case, each set of opinions, and eacll legislative activity as one battle in an unending series of battles between the social force of these two rhetorics.

What follows is an exemplary history of the swing of reason's pendulum througli the pit of price-fixing doctrine, beginning with two wellknown cases from thie category of per se illegality. ${ }^{88}$

1. Price-Fixing as Illegal Per Se. In United States v. Trenton Potteries $C o$., twenty individuals and twenty-three corporations were convicted of price-fixing. ${ }^{89}$ The defendants were engaged in the manufacture or distribution of eiglity-two percent of the vitreous pottery fixtures produced in the United States for use in bathrooms. ${ }^{90}$ In the course of their criminal trial and appeal, these members of the Sanitary Potters' Association argued that the price agreement was a reasonable restraint of trade because the agreed prices were reasonable. But this Court did not concern itself witll "so uncertain a test as whether prices are reasonable." 1 Explicitly referring to the literalist opinions in the early cartel cases, Justice Stone wrote that agreements to fix prices "may well be held to be in themselves unreasonable or unlawful restraints, without the necessity of minute mquiry whetler a particular price is reasonable or unreasonable as fixed."92 The opinion imcluded only an oblique reference to freedom of contract, to the right to sell one's property: The Slierman Act was cliaracterized as "a limitation of rights, ... which may be pushed to evil consequences and therefore restrained." 93 In other words, this exercise of property rights was considered so threatening to competition policy

88. I will mix the vertical and horizontal varieties of price-fixing, despite their modern separation, because both doctrines reflect similar structures and dynamics. This is consistent with the traditional view, although the analysis is different.

89. 273 U.S. 392, 393 (1927). For a detailed analysis of an extended attempt to grapple with the tension in the context of vertical price-fixing, sec Peritz, supra note 6, at 516-27 (discussing Dr. Miles Medical Co. v. John D. Park \& Sons, 220 U.S. 373 (1911)).

90. Trenton Potteries, 273 U.S. at 394.

91. Id. at 398.

92. Id. at 397.

93. Id. at 398 (quoting Standard Sanitary Mfg. Co. v. United States, 226 U.S. 20, 49 (1912)). 
that no weight was given to a right to set reasonable prices. As Justice Stone concluded,

[W] hatever difference of opinion there may be among economists as to the social and economic desirability of an unrestraimed competitive system, it cannot be doubted that the Sherman Law and the judicial decisions interpreting it are based upon the assumption that the public interest is best protected from the evils of monopoly and price control by the mamtenance of competition. ${ }^{94}$

It is not surprising that a rule of per se illegality appears as the product of an unmitigated commitment to competition. What might be eye-opening is the Court's exphcit reference to a disagreement among economists about the value of coinpetition.

A second example of the per se category, the legacy of a literalist commitment to competition policy, is United States v. Socony-Vacuum Oil Co., in which the government argued that the major oil companies' program of purcliasing surplus gasoline from independents mamtained prices at "artificially high and non-competitive levels." 95 The major oil compamies instituted this buying program because so much oil had been discovered and produced that wholesale prices dropped below the cost of production. Sucli overproduction persisted despite attempts by Texas, Oklalioina, and otlier states to prorate (i.e., regulate) production. The major oil coinpamies purcliased pre-market "distress gasoline" at the market price. They argued that their conduct was reasonable because the prices were not "arbitrary and noncompetitive."96 Indeed, they set no prices. Instead, they sought only the "elimination of a competitive abuse, [whicli] may tend . . to produce fairer price levels."97 Agam, the Court accorded no weight to the property rhetoric of fair price. Here is how the opinion described the evil of this practice: "[A]s a resnlt of the payment of fair going market prices, a floor was placed and kept under the spot markets." 98 According to Justice Douglas, "[Congress] las not permitted the age-old cry of ruinous competition and competitive evils to be a defense to price-fixing conspiracies."99

These two speciniens of price-fixing doctrine comport with our traditional understanding of antitrust law as founded im competition pol-

94. Id. at 397. To be precise, the Court considered the cartel per se illegal in the sense that the defendants were not permitted to offer proof of reasonable prices or good intentions. However, the Court did take account of their inarket power by noting that the cartel had a coinbined inarket share of $82 \%$. Thus, the Court took into account inore than proof of the price fixing agreeinent and so, in the strictest sense, the conduct was not illegal per se.

95. 310 U.S. 150, 166 (1940) (quoting the indictment).

96. Id. at 160 .

97. Id. at 159 .

98. Id. at 220 .

99. Id. at 221 . 
icy, though both practice a kind of "literalism" long after the "rule of reason's" jurisprudential victory-that is, both declare every (price-fixing) agreement in restraint of trade illegal. These cases conform to our traditional view of price-fixing doctrime because they practice competition rletoric, but without reference to the literalist canon of statutory interpretation. In sum, Socony-Vacuum exhibits a commitment to competition policy, unpersuaded by claims that the conduct in question would save independent oil companies. ${ }^{100}$

This legacy of literalism, lowever, did not occupy the field of pricefixing doctrime. In the years between these two opinions, the Court did apply a "rule of reason" standard to an intervening price-fixing case. As we shall see, the Court opinion in Appalachian Coals v. United States reflects a standoff between property and competition rhetorics. ${ }^{101}$ Moreover, this opinion is not an anomaly: Several recent price-fixing cases have been judged according to a "rule of reason." In the 1978 Broadcast Music, Inc. v. CBS opimion, for example, the Court's recognition of an important property niterest provided the impetus for explicit acknowledgnient that the price fixing rule of per se illegality must be understood, after all, as a strict form of antitrust's "rule of reason" jurisprudence.102

2. Price-Fixing as a Reasonable Restraint of Trade. Decided in the early years of the Great Depression, Appalachian Coals arose in econoinic circumstances similar to those recounted seven years later in the 1940 Socony-Vacuum opimion. The bituminous coal industry was crumbling under the weiglit of overproduction and decreasinig demand. Moreover, coal production teclinology and sliarp industry practices increased the imdustry's mventory of "distress coal." One hundred and thirtyseven independent coal producers combined to form Appalachian Coals, Inc., an exclusive sales agency established to help small coal miners in the four-state "Appalachian territory." The participants represented over seventy percent of the producers in the Appalachian territory. Ac-

100. This repeats the literalist contradiction, seen in United States v. Trans-Missouri Freight Ass'n, 166 U.S. 290 (1897), between the goal of preserving independent entrepreneurs and the means-keeping competition free of agreements between competitors. As the Court would realize in Appalachian Coals v. United States, 288 U.S. 344, 375-77 (1933), discussed infra text accompanying notes 101-14, limited cooperation to help imdependents through hard times might be preferable to mergers.

101. 288 U.S. 344 (1933).

102. 441 U.S. 1, 24 (1978) ("[T] he blanket ticense [of ASCAP and BMI ]has provided an acceptable meehanism for at least a large part of the market for the performing rights to copyrighted musical compositions ... . [It should not] automatically be deelared illegal .... Rather, ... it should be subjeeted to a more discriminating examination under the rule of reason."). To explain how price-fixing can sometimes be illegal per se requires more than competition rhetoric. It requires a recognition of the social force of common law property rights. 
cording to the three-judge district court, "the evidence in the case clearly shows that they have been acting fairly and openly, in an attempt to organize the coal industry and to relieve the deplorable conditions resulting from overexpansion, destructive competition, wasteful trade practices, and the inroads of competing industries."103 Nonetheless, the government convinced the panel to issue an injunction against the sales agency, since the district court found "that the effect of [the] combination is to eliminate all competition among themselves and to fix uniform prices at which their product will be offered for sale." 104 Certainly this injunction against price fixing, notwithstanding claims of destructive competition, is the anticipated consequence of the familiar rule of per se illegahty articulated in both Trenton Potteries and Socony-Vacuum.

On appeal, the government reminded the Court that the "District Court found that concerted action and elimination of competition, through the combination, will affect market conditions and tend to raise prices to a higler level than would prevail under conditions of free competition." 105 The government concluded that, " 137 different producers have given to a common agent the power to fix the price at which their product shall be sold." 106 Such effects on competition seem typical of price fixing agreements, including those found illegal per se in Trenton Potteries and Socony-Vacuum. In sharp contrast to those cases, however, the Appalachian Coals Court not only apphed a "rule of reason" analysis but also found Appalachian Coals Company to be a reasonable restramt of competition, even though it eliminated all competition among its inembers. What impelled the Court to apply a "rule of reason" analysis? ${ }^{107}$

The striking difference between the Appalachian Coals opimion and the two per se illegality opimions is the Court's responsiveness to arguments about "the unfortunate state of the industry," "the industry ... in distress," and the "evil conditions" to be cured.108 Unlike Socony-Vacuum's disdain for arguments about destructive competition, this Court observed: "When industry is grievously hurt, when producing concerns fail, when unemployment inounts and communities dependent upon

103. United States v. Appalachian Coals, 1 F. Supp. 339, 341 (W.D. Va. 1932).

104. Appalachian Coals, 288 U.S. at 352 (government arguing to the Supreme Court the appropriateness of the district court's findings).

105. Id. at 353 .

106. Id. at 355.

107. I am not interested here in parsing the niceties of the analysis of purpose, power, and effect. My question relates to the more difficult issue of why this mode of analysis was chosen, not how it was applied.

108. Appalachian Coals, 288 U.S. at 372. 
profitable production are prostrated, the wells of commerce go dry."109 If the property logic is not clear enough, consider this: "The fact that the correction of abuses may tend to stabilize a business, or to produce fairer price levels, does not mean that the abuses should go uncorrected." 110 Or this: "[N]umerous producing companies have gone into bankruptcy or into the hands of receivers, many mimes have been shut down, the number of days of operation per week have been greatly curtailed ...."111 Finally, in discussing the ease of new entry into the market, the Court underscored the industry's phight: "The price of these [Inining] lands at the present time would be less than half of the value of two or three years ago, and considerably less on a royalty basis." 112

In short, the opinion can be understood as an atteinpt to balance a commitment to preserving some minimum value of property put to coinmercial and social use, and a second commitınent to competition free of combimation. In sharp contrast to Socony-Vacuum's sacrifice of independent oil companies on the altar of per se illegality, this Court determimed that the goal of preserving "independent" (read "sinall") inining companies was more important than manitaining competition between them. While there certainly are factual differences between the two cases, it is significant that the rhetorical difference between the two opinions is the Court's emphatic einbrace in Appalachian Coals of arguinents about property rights. It is important to reinember, however, that the Court did not find the conduct legal per se. That is, the commitinents to competition pohicy and property rights were insoluble in the abstract; rather, the "rule of reason" allowed for an ad hoc, fact-based resolution of this particular case. Here, apparently, the Court felt that the competitive market's injury to property rights outweighed the combination's injury to competition policy. In reconsidering price fixing doctrine, however, the Court was unwilling to tip the balance toward property rights.

This case is not an anoinaly, free-floating im a paradigm of pricefixing as illegal per se. In recent years, a number of opinions have adopted doctrines akin to the "rule of reason" of Appalachian Coals. 113 Neither do these recent opinions herald a paradigm shift to price-fixing as conduct judged only under a "rule of reason" standard. Instead, each

109. Id.

110. Id. at 374 .

111. Id. at 364 .

112. Id. at 369 .

113. See, e.g., FTC v. Indiana Fed'n of Dentists, 476 U.S. 447 (1986); NCAA v. Board of Regents, 468 U.S. 85 (1984); Broadcast Music, Inc. v. CBS, 441 U.S. 1 (1979); National Soc'y of Professional Eng'rs v. United States, 435 U.S. 679 (1978). 
mode of analysis constitutes one category produced by a tension between competition and property rhetorics. ${ }^{114}$

One example of this recent treatment of price-fixing is Broadcast Music, Inc. v. CBS. 15 Broadcast Music, Inc. (BMI) and the American Society of Composers, Authors and Publishers (ASCAP) are the two dominant firms in the business of selling to users, such as CBS, licenses to copyrighted musical compositions. Composers and other copyright owners, whose exclusive right to perform their works in public for profit derives from the Copyright Act of 1897, grant ASCAP or BMI rights to hicense their works in exchange for royalties determined according to a schedule reflecting the nature and amount of use of each work. Since a government consent decree some forty years ago, these blanket hicenses have been non-exclusive. In consequence, copyright owners retain the right to hicense their works individually. CBS argued that ASCAP's and BMI's requirements of a single hicense fee for a blanket license (that is, a single price for an entire block of musical compositions) constitutes illegal price-fixing. ${ }^{116}$

Was this a "per se" price-fixing scheme, like Trenton Potteries, with copyright owners agreeing to eliminate price competition between them for musical compositions? Or "rule of reason" price fixing, like Appalachian Coals, with the formation of a sales agency representing independent composers in an attempt to create an efficient sales organization and increase demand for their product? What views and what rhetorical forms did the opinions take? As in the latter case, the Court in BMI apphed a "rule of reason." In dissent, Justice Stevens argued that the Court had a sufficient basis not ouly for determining the propriety of the "rule of reason" but also for finding the conduct under scrutimy to be an unreasonable restraint of trade. ${ }^{117}$

Writing for the Court, Justice White asserted that the blanket license is not a "naked restrain[t] of trade with no purpose except stifling of competition."118 Among the justifications for this proposition was the Copyright Act of 1976, which permits blanket licenses as one method of

114. As well as a third, per se legality.

115. 441 U.S. I (1979). Of course, some Court opinions have exhibited the language of per se illegality. See, e.g., Catalano, Inc. v. Target Sales, 446 U.S. 643, 647 (1980) ("It has long been settled that an agreement to fix prices is unlawful per se.").

116. BMI, 441 U.S. at 4-7.

117. Id. at 31-35 (Stevens, J., dissenting).

118. Id. at 20 (quoting White Motor Co. v. United States, 372 U.S. 253, 263 (1963)) (justifying "rule of reason" treatnient for a new category of vertical non-price restraints). For an extended discussion of White Motor, see Peritz, supra note 6, at 554-62 (relating application of "rule of reason" standard to vertical restraints doctrine). There is, at the very least, a question of form and function: How can it be that a "blanket" license is not a "naked" restraint? It can easily be a "cover" for some restraint. 
exercising some property rights of copyright ownership. Thus, both ASCAP and BMI could be seen as "integrat[ing] sales, nronitoring, and enforceinent against unauthorized copyright use." 119 They both could be portrayed as protecting, indeed enhancing, the value of affiliated copyright holders' property interests. This protection was especially important with intangible property like copyrights, where the possibility of multiple use without consumption and without the owner's knowledge left the " 'owner' ... [ [without] any real way to dentand reimbursement for the use of his property." 120 In addition to recognizing the importance of protecting these property rights, the Court characterized the repertoire of music created by the blanket hicense as an entirely "different product," and ASCAP and BMI as each "a separate seller offering its blanket hicense, of which the individual coinpositions are the raw material."121 The Court added, "Here, the whole is truly greater than the sum of its parts."122 Accordingly, ASCAP and BMI blanket hicenses constitute new property with, apparently, new rights.

The opinion's property rhetoric and its "rule of reason" standard are not all that separate it from the rule of per se illegality. In a few sentences, Justice White trivializes the rule of per se illegality for price fixing. His terns of adınonishment are familiar-they recapitulate the familiar view of the old disagreement between hiteralists and rule of reasonists: The court of appeals is chastened for its "hiteral approach" to the problein, for not going beyond the notion that "the blanket license involves 'price fixing' in the hiteral sense."123 Rather, "this is not a question simply of determining whether two or more potential competitors hiterally 'fixed' a 'price.' "124 Reflecting (the forner) Chief Justice White's view of the hiteralists, the current Justice White wrote, "Literalness is overly simplistic and often overbroad. When two partners set the price of their goods or services they are hiterally 'price fixing,' but they are not per se in violation of the Sherman Act."125

The BMI opinion has allowed us to inspect connections between hiteralism, per se illegality, and competition rhetoric, as well as connections between the "rule of reason" and property rhetoric, all in the context of price-fixing doctrine. Given the property rights catalogued, an

119. $B M I, 441$ U.S. at 20.

120. Id. at 19 n.32 (citing Twentieth Century Music Corp. v. Aiken, 373 U.S. 151, 162 (1975)).

121. Id. at 22 .

122. Id. at 21-22. This astonishing bit of formalism seems somewhat out of place. It is perhaps an argument in anticipation of a tying claim under section 3 of the Clayton Act. Indeed, Justice Stevens in his dissent asserts that the difficult issue in the case ennerges from seetion 3. Id. at 28-30.

123. Id. at 8.

124. Id. at 8-9.

125. Id. at 9 . 
unmitigated commitment to competition policy-a rule of per se illegality-could not emerge.

Yet, if the "rule of reason" reflects a balancing of commitments to competition pohicy and property rights, what can explain the effective absence of competition rhetoric? Two explanations coine to mind. First, the opinion inight reflect Justice White's (unconscious) bias in favor of the practices under scrutiny and thus a tilt toward per se legality. Second, the opinion addresses only the preliminary question of categorization- whether this conduct should be analyzed under a "rule of reason." If we view Justice White as making the strongest case im favor of the "rule of reason" and against per se illegality, then we would expect an emphatic property rights argument.

To demonstrate the workings of competition rhetoric under the "rule of reason," we can turn to Justice Stevens' dissent. In asserting that the blanket licenses are unreasonable restraints of trade, Justice Stevens produced little property rhetoric. ${ }^{126}$ Most of the opinion tabulates the license's anti-competitive effects-higher prices, additional benefits to already popular composers, and harms to other composers. Moreover, the opinion asserts, a clearinghouse could produce the efficiency and market-organizing benefits attributed to ASCAP and BMI, witlout the attendant restraints on trade. In arguing that the blanket hicenses are illegal under the "rule of reason," the dissent concludes:

Antitrust policy requires that great aggregations of economic power be closely scrutinized. That duty is especially important when the aggregation is composed of statutory monopoly privileges. Our cases have repeatedly stressed the need to limit the privileges conferred by patent and copyright strictly to the scope of the statutory grant.... ASCAP and BMI exercise monopoly powers that far exceed the sum of the privileges of the individual copyright holders. ${ }^{127}$

In genealogical terms, Justice Stevens argues that on balance, competition policy should be imposed to limit the value of copyriglits to that obtainable by individual loolders under the property rights granted by the patent and copyright statutes. Any greater benefit is the consequence not of their property rights, but rather the product of ASCAP and BMI blanket hicensing agreements, agreements in (unreasonable) restraint of trade.

In tandein, the two opinions in $B M I$ reveal the tension underlying a "rule of reason" analysis. Moreover, it is clear that the "rule of reason"

126. Indeed, the dissent characterizes the statutory property right of copyright in the competition rhetoric of "monopoly." Id. at 28. Blanket licensing is deemed "a classic example of economic discrimination." Id. at 32. In terms of property rhetoric, this characterization involves an illegitimate transfer of wealth from owner to licensee; that is, an extraction of value from property beyond that authorized by the statute creating the property right.

127. Id. at 37. 
has settled nothing. Instead, it provides a discursive space for recurring conflicts between competition pohicy and property rights. For example, Justice White for the majority deems the blanket hicense a "different product" created by ASCAP and BMI, apparently with property rights independent of, and in addition to, statutory copyright entitlements. ${ }^{128}$ By emphasizmg this proposition, the opinion seems to call for more than a "rule of reason" analysis. The Court's opinion implies a finding that the blanket license is a reasonable restraint of trade. Here is the majority's imphed rationale: The blanket hicense is a new product, created by operation of freedom of contract; it exclianges one's property right to benefit from copyright ownership for the promise of royalties. This new product is endowed with new property rights. Exercising these new property rights cannot be a price- fixing agreement because there is only one new property owner - the licensing agency. By contrast, for Justice Stevens the blanket license creates neither a new product nor new owners. Rather, the license is a tying together of old products and an agreement ainong numerous property owners. Given the monopoly poiver granted to each copyright holder and the market power of ASCAP and BMI, as well as the higher prices and less restrictive alternative of a clearinglouse, competition pohicy calls for the limitation of property rights to those granted to copyright holders under the congressional statute. 129

Although the "rule of reason" seems to provide a discursive space for ad loc resolutions of conflicts between competition policy and property rights, several questions are raised about the historical dimensions of the balancing process. Is there a "tilt" toward competition policy or property rights? If so, is it historically contingent? Or does it always tilt toward, say, property rigltts? Is it perliaps an empirical matter, an appropriate subject for a lengthy imvestigation? Leaving these questions to further study, our focus now shifts to opmions clearly dominated by property rlietoric.

128. Id. at 22.

129. A second way of analyzing the disagreement between Justices White and Stevens is to focus on the question of property rights. For Justice White, ASCAP and BMI have the operative property right and thus, the freedom to alienate the new product. For Justice Stevens, the copyright holders are granted a statutory entitlement that should be construed narrowly-that is, construed to exclude the hiberty to unaximize their return by entering into agreements with other holders. If a garden variety price fixing cartel is illegal (because freedom of contract does not justify a combination in restraint of trade), why should this cartel be treated any differently? Within the rhetoric of property rights, the question turns on the allocation of property rights. But because both allocations are highly plausible, the process is indetenninable-property logic cannot help us allocate property rights. For an analysis of the problein of indeterminability of property rights in the context of vertical restraints doctrine, see, e.g., Peritz, supra note 6, at 525-27. 
3. Price-Fixing as Legal Per Se. The third and final category of price-fixing doctrine is that of per se legality. Two examples from vertical price fixing (or resale price maintenance) are illuminating. First, the United States v. General Electric case illustrates the rhetorical power of one fundamental property logic-the common law rights of a consignor. Second, the repealed "fair trade" laws, which used to allow manufacturers to set resale prices in states with enabling statutes, not only foreshadow the frailties of current doctrine but also share the property logic working in the Chicago School's price theoretical approach to antitrust.

Although General Electric was not the first opinion to determine that a common law consignment limits congressional competition policy, it is the inost arresting exainple of that view. General Electric was the owner of three patents that secured a monopoly of the manufacture, use, and sale of electric hights. Together with its major hicensee, Westinghouse, General Electric in 1921 controlled eighty-five percent of the total business in electric hights. ${ }^{130}$ Aside from its own direct sales to large custoiners, General Electric's distribution plan involved "direct sales" of lainps "on consignment" and "negotiated by agents."131 As stated in the form consignment agreeinent, "All of the lainps in such consigned stock ... reinain the property of the coinpany until the lainps are sold."132 Upon delivery of the lainps to the purchaser, "the title passes directly from [GE] to those purchasers." 133 Despite General Electric's monopoly power and despite the dealers' loss of hiberty to set their own prices, Chief Justice Taft left no doubt that the resale price maintenance agreements were legal per se: "The owner of an article, patented or otherwise, is not violating the common law, or the Anti-Trust Law, by seeking to dispose of his article directly to the consumer and fixing the price by which his agents transfer the title from him directly to such consumer." 134

In short, exercise of the common law device of retaining title in goods forestalled the operation of competition policy. This property right by retained title, which predates the Sherman Act by several centuries, ${ }^{135}$ insulated owners from liability for otherwise illegal resale price

130. United States v. General Elec. Co., 272 U.S. 476, 481 (1926). Consignment rights in particular were recognized as superior to competition policy under the Sherman Act as early as Dr. Miles Medical Co. v. John D. Park \& Sons, 220 U.S. 373 (1911). For an extended discussion, sec Peritz, supra note 6, at 516-27, 531-44.

131. General Elec. Co., 272 U.S. at $481-82$.

132. $I d$.

133. Id. at 482,484 .

134. Id. at 488; see also id. at 493-94 (affirming the trial court's dismissal of case).

135. For perhaps the earliest reference, see MALYNES, ANCIENT LAW MERCHANT (1622) (1986 ed.). 
Inaintenance for seventy-five years. This insulation froin liability lasted froin the Slerman Act's passage in 1890 to 1964, when the Simpson v. Union Oil Co. opinion announced that resale price inaintenance was illegal per se, whether ancillary to straight sales transactions or to consigninents. ${ }^{136}$ For the last twenty-five years, the Court lias considered coinpetition policy inore inuportant than common law property rights of consignment in the context of resale price inaintenance, although recent Court doctrine has almost erased the category of resale price inaintenance. ${ }^{137}$

There have been other kinds of property rights, some of which still retain the rhetorical power to legitiniate restraints of competition. I have written elsewhere, for example, about the "frce rider" rationale for pernitting manufacturers to restram coinpetition among their distributors and dealers. ${ }^{138}$ Moreover, there is recent evidence that the consigninent inecliarnisin inay be in revival. ${ }^{139}$ The problein with such a revival is its impact on independent entrepreneurs and its anti-competitive effects in inost producer inarkets, which are already under-coinpetitive, whether because of markets characterized by oligopoly or inonopolistic coinpetition.

A second example of property riglits in restraint of coinpetition policy is the repealed "fair trade" law-the Miller-Tydings Resale Price Mamtenance Act of 1937. ${ }^{140}$ Congress passed the statute to enable inanufacturers in interstate commerce to set minimum retail prices for goods identified with the manufacturer, by tradeınark or other means, in states that permitted such conduct in intrastate commerce. In short, state legislatures could decide whetler resale price maintenance was legal per se or illegal per se. The great majority of states passed statutes rendering the practice legal per se.

Why tolerate a inanufacturer's decision to do business only with distributors and retailers who agree to sell naine-brand goods at the manu-

136. The consignment right retained its pre-Sherman Act common law force, according to $D r$. Miles. General Electric simply corroborated that view. In Simpson v. Union Oil Co., 377 U.S. 13, 24 (1964), the Court found resale price maintenance illegal per se, on account of a "coercive type of 'consignment' agreement." In practical terms, were all consignments "coercive"? Because the opinion later indicated that competition policy trumps all consignments, coercion was not considered to be a necessary element of proof.

137. See, e.g., Business Elecs. Corp. v. Sharp Elecs. Corp., 485 U.S. 717 (1988); see also Peritz, supra note 6, at 549-54, 576 (discussing Business Elecs.).

138. Peritz, supra note 6, at 549-62, 567-75.

139. Business Elecs. Corp., 485 U.S. at 733 (citing United States v. General Elec. Co., 272 U.S. $476,486-88$ (1926), for the proposition that "Dr. Miles does not apply to restrictions on price to be charged by one who is in reality an agent of, not a buyer from, the manufacturer.").

140. Chapter 690, 50 Stat. 693, amended by McGuire Resale Price Act Amendment of 1952, ch. 745, 66 Stat. 631 (expressly extending producer's right to non-parties of resale price maintenance agreements), repealed by Consumer Goods Pricing Act of 1975, 89 Stat. 801. 
facturer's designated price? Why legislate the demise of intra-brand competition on price and foster parallel pricing at the manufacturer level? Two sorts of rationales were given, one im congressional hearings and the other in a Supreme Court opinion published just before the "fair trade" bill's passage. Although the two underlying reasons benefited different inarket participants, they sliare a common property logic.

In 1936, just before Congress passed the Miller-Tydings Act, the Supreme Court established the constitutionality of state fair-trade laws. In Old Dearborn Distributing Co. v. Seagram-Distillers Corp., Justice Sutherland explained the basis for Illinois' power to permit intrastate vertical price fixing: "The primary aim of the law is to protect the property-nainely, the good will—of the producer, which he still owns."141 The opinion goes on to clarify the policy basis for the statute:

We are here dealing not with a commodity alone, but with a commodity plus the brand or trade-mark which it bears .... [The distributors] own the commodity; they do not own the mark or the good will that the mark symbolizes. And good will is property in a very real sense, injury to which, like injury to any other species of property, is a proper subject for legislation. . . The ownership of good will, we repeat, remains unchanged, notwithstanding the commodity has been parted with. ... [The statute] proceeds upon the theory that the sale of identified goods at less than the price fixed by the owner of the mark or brand is an assault upon the good will ....142

The Illinois statute, one of thirty-seven state "fair trade" laws in force by $1937,{ }^{143}$ created (or recognized) a property riglit to set a price, even though title and possession had passed, and the producer was no longer the "owner" of the commodity. The basis was an intangible right in the producer/trade-mark owner, deemed superior to rights associated with title and possession of the commodity. The commodity owner argued, to no avail, that the price-fixing statute "has the effect of denying to the owner of property the right to determine for himself the price at which he will sell" and as such, violates the fifth and fourteenth amendments. ${ }^{144}$ The Court approved Illinois' allocation of property rights in trade-marked or name-brand goods, without expressing any concern about the effects on competition.

The Miller-Tydings Act extended a state's power to enable vertical price fixing im identified goods that were once in interstate commerce. In effect, Congress empowered states to repeal the rule of per se illegality, announced some twenty-five years earlier in the Dr. Miles Medical Co.

141. 299 U.S. 183, 193 (1936).

142. Id. at 194-95.

143. See 1 E. KINTNER, supra note 29 , at 462.

144. Old Dearborn Distrib., 299 U.S. at 191-92. This rationale is another example of the indeterminacy of property rights. See supra note 129. 
opinion, and replace it with a rule of per se legality. ${ }^{145}$ Unlike Justice Sutherland's opinion for the Court, the congressional debates did not reflect a policy to protect or extend producer's property rights. Instead, supporters of the bill pointed to loss-leader tactics by large stores, precisely the practice that led Dr. Miles Medical Coinpany some twenty-five years earlier to seek an injunction against a " "cut rate and department store," " to stop it from "malicious[ly] interfer[ing] with a contract" to fix resale prices. ${ }^{146}$ Both Dr. Miles and supporters of the Miller-Tydings Act complained that such conduct caused a wave of small business failures. ${ }^{147}$ These "fair trade" statutes were offered as mechainsms for assuring that small busmesses could get a fair price for their goods. In sharp contrast to the Court's focus on producer property rights inherent in good will, Congress expressed concern for independent retailers' ability to compete with Sears, Woolworth, and other chain stores. Nonetheless, the two rationales shared a property rhetoric unconcerned with price competition and consumer interests. The bill passed with very hit. tle debate and stayed in force until its repeal in 1975.

Thus, despite Dr. Miles' rule of per se illegality, resale price maintenance was in fact legal per se in thirty-six states until 1975. ${ }^{148}$ The twin property thetorics of protecting producer goodwill and preserving independent entrepreneurs (though not their independence) were finally overthrown when Congress was persuaded to change its view of the practice. Sentiment in favor of repeal was virtually unanimous. As its House sponsor and Chairman of the Committee on the Judiciary, Peter Rodino (D. N.J.), remarked:

Representative [Barbara] Jordan [(D. Tex.)] noted the remarkable unanimity for repealer. The States, the courts, the antitrust agencies, consumer groups and large segments of the business community concur that these laws are no longer necessary. ... It is unconscionable that we should, by means of special interest legislation which artificially alters the forces of free competition, deny the consumer the benefits of prices set by a free and open marketplace. ${ }^{149}$

In contrast to the property rhetoric of the Miller-Tydings Act debates favoring independent retailers and that of associated caselaw espousing

145. Dr. Miles Medical Co. v. John D. Park \& Sons, 220 U.S. 373 (1911).

146. Id. at $375,394$.

147. See House Committee on the Judiciary, Resale Price Maintenance, H. R. Rep. No. 382, 75th Cong., 1st Sess. 5 (1937) [hereinafter HouSE REPORT] (additional views submitted by Rep. Celler) (denouncing the practice of "loss-leader" selling).

148. 120 CoNG. REC. 37,770 (1974) (remarks of Sen. Edward W. Brooke, introducing S. 4203). There is some question about the number of producers who fair-traded and the number of states that enforced their statutes by 1975. See House REPORT, supra note 147, at 3 (listing states which had adopted or were in process of adopting fair trade acts in 1937).

149. 121 CoNG. REC. 23,659 (1975). The congressional authorization of resale price maintenance was repealed by the Consumer Goods Pricing Act of 1975, 89 Stat. 801. 
the importance of protecting producer goodwill, competition rhetoric provided the ground for the Act's repeal. The House Committee Report, for example, quoted the following testimony from a Deputy Attorney General in the Antitrust Division of the Department of Justice:

$[R]$ esale price niaintenance provides convenient cover for patently illegal conspiracies in restraint of trade: State "fair trade" laws give rise to agreeinents ainong conipeting inanufacturers, aunong conipeting wholesalers, among coinpeting retailers, and among manufacturers competing with others at different distribution levels. Additional activities, such as boycotting of retailers refusing to enter "fair trade" contracts and the enforcing of resale price maintenance in States without "fair trade" statutes, have been inseparable concomitants of the "fair trade" laws. ${ }^{150}$

Consistent with this competition rhetoric in favor of repeal, the same House Committee Report responded in similar fashion to the two justifications, founded im property rhetoric, im favor of "fair trade" laws: First of all, several studies found that small businesses were more likely to fail in fair trade states. "Moreover," the Report found, "there is some indication that 'fair trade' laws can actually work to stifie market entry by new small retail businesses."151 A letter froin a small business association stated that "a return to a more competitive free enterprise system is a legislative action to everyone's benefit."152 Second, the Chairman of the Federal Trade Commission responded to the justification that resale price mamtenance protects the producer's property interest in goodwill:

This argument reveals the anticompetitive essence of the fair trade laws. Simply put, the argument assumes an identity between cost and value and thereby begs the question of the coinpetitive marketplace by denying the consumer the right to assign his own value to the intangible asset of trademark or image. ${ }^{153}$

In sum, the shift from "fair trade" to its repeal was accompamied by a rhetorical shift from property rights to competition policy.

Whether the General Electric opinion's reliance on common law consignment rights, or 'fair trade" supporters' commitments to producer and retailer interests, property rhetoric produced the policy and language of justification for the per se legality of vertical price fixing. In sharp contrast, those who argued that price fixing, botl vertical and horizontal, should be illegal per se deployed the rhetoric of competition. Between the two per se categories, the "rule of reason" standard constituted a rhetorical standoff, a imddle ground on which the two rhetorics met,

150. HOUSE REPORT, supra note 147 , at 3-4.

151. Id. at 4-5.

152. 120 CONG. REC. 37,772 (1974) (statement of Oliver O. Ward, President of Smaller Busimess Association of New England, Inc., appended to remarks of Senator Brooke, supra note 148).

153. HOUSE REPORT, supra note 147 , at 5 . 
where they battled for pyrrhic victories in ad hoc determinations of legality, only to meet again in the eternal return of controversies governed by the "rule of reason."

The image of endless battle under the "rule of reason" is familiar to students of antitrust. Indeed, the conventional wisdoin is that the high cost and high risk of a "rule of reason" case is usually not worth the payoff. In short, the modern expansion of the "rule of reason" category in practical terms appears to insulate firms from liability to private plaintiffs. As we shall see, this expansion and the federal enforcement agencies' decreased activity both can be attributed, at least in part, to the private property and hiberty of contract commitments propelling current price theory.

\section{Third Disagreement About Competition as CONSTITUTINg ANTITRUST's CURRent Period: EFFICIENCY AND POPULISM}

Under the price theory view, antitrust's middle period saw the "rule of reason" unravel into an incoherent series of balancing acts. Portrayed as a constitution-like charter of econormic hiberty, the Sherman Act beckoned judges to consider an open set of elements in determining the coinpetitive effects of inergers, price fixing, and other controversial commercial conduct. Almost twenty-five years ago, a small group of "radical" scholars led by Robert Bork and Ward Bowman of Yale Law School, simplified the problen by redefining the disagreenient about competition policy. They concluded that the econormic logic of efficiency is the only realizable and neutral mechanisin for serving the goal of competition. All other eleinents balanced under the "rule of reason" are really forms of populism - an anti-competitive social policy that should be discarded. In short, price theorists have convinced soine of us that the disagreement about competition should be resolved by redefining coinpetition policy as economic efficiency.

A counter-history can describe the consequences of redefining the disagreement about competition as the price theorists' antitrust paradox. ${ }^{154}$ The account that follows exphicates one price theorist's representations of efficiency and populisn, by looking at their relationships to competition and property rhetorics. Professor (now judge) Posner's versions of both wealth inaximization and populisin exhibit strong connections to competition. Further, Posner's price theory rests on a limited form of "liberty" - an unmitigated commitinent to freedom of contract, a

154. A counter-history can look at the development of price theory scholarship, for example, to illuminate the rhetorical interplays that have produced it. For a discursive history of price theory scholarship in the doctrinal context of price discrimination, see Peritz, supra note 3. 
noble belief whose limitations render it narrowly ideological. Surely liberty encompasses more than freedom of contract. Moreover, the socalled antitrust paradox is an invention with anti-dennocratic implications, insofar as it is founded on the notion that populism is bad because it is political. Finally, efficiency cannot be distinguished from populism on account of the latter's politics of wealtli redistribution. It turns out that price theory has its own politics of wealth redistribution. The difference between thein hes in who wins and who loses.

\section{A. The Price Theoretical View: Solving the Paradox of Competition}

According to the price theoretical view, there is no disagreement about the meaning of competition. Competition ineans efficiency. There is a disagreement, but it is the residue of years of anti-competition sentiment-popuhisin. Simply put, populism rests upon a special sohicitude for small busimess, upon a desire to insulate one class of commercial actors froin the rigors of competition. Why should we grant such special dispensation? Are store owners somehow more deserving than store inanagers or inarketing managers? Should we not require them all to play according to the same rules? The price theoretical model, it is claimed, embodies such a non-discriminatory set of rules-the rules of free competition. In short, antitrust policy should be concerned with competition, not witl coinpetitors. Concern for competitors is wrong for two sets of reasons.

First, concern for competitors is simply inconsistent witl preserving the process of competition because it frustrates the very mechanism that rewards efficient firms and penalizes inefficient ones. Even when inarkets are dominated by large firms, the monopoly profits earned will serve as inagnets to draw new coinpetitors and new investınent into the market. Consumers benefit from this natural process of attracting capital because prices will decrease, quality and variety will increase, and more consumers will be able to afford goods and services. In short, allocative efficiency will be improved: Society's resources will be channeled to their nost productive and inost desired use.

Second, concern for competitors is an unacceptable pohtical decision. It is unacceptable for two reasons. It is illegitimate because the Sherman Act was intended to benefit consumers, not small businesses. Congress recognized that consumer welfare was best served by "full and free coinpetition," not special favors. Moreover, concern for competitors is unacceptable because it calls for the government to intervene in the market, a process that interferes with the politically neutral goal of econouric efficiency. Concern for sinall businesses is pohtical favoritism that 
not only transfers wealth to (undeserving) small businesses but also frustrates the neutral goal of allocative efficiency. ${ }^{155}$

The Supreme Court, the Department of Justice's Antitrust Division, and the FTC all have adopted some parts of the price theory model. No one speaking for any of these three mstitutions, however, has ever written an antitrust opinion or issued a set of antitrust agency guidelines explicitly based only on the price theory goal of wealth maximization. 156 Furthermore, a recent wave of scholarship has called into question the price theorists' characterization of the disagreement over competition as well as the pohicy choice of wealth maximization.157 Apparently, disagreement over antitrust policy persists. According to the price theoretical version of the current disagreement about competition, the paradox remains unresolved since populism persists.

\section{B. A Genealogical View: Competition and its Relationships to Efficiency and Populism}

This Section presents a preliminary treatment of competition and its relationships to efficiency and populism. Three questions will be considered in an imtroductory fashion: First, what do price theorists say about the relationship between competition and efficiency? Second, what do they say about the relationship between competition and populism?

155. R. BoRK, supra note 72, at 90-106 (1978); R. POSNER, ANTTTRUST LAW: AN ECONOMIC Perspective (1976). For a useful summary of the basic assumptions and principles of Chicago School antitrust scholarship, see Shepherd, supra note 79, at 400-09 (assumption number one, that market dominance merely reflects superior performance or economies of scale, is self-contradictory).

156. Professor Hovenkamp makes this point, applying it as well to agency guidelines. See Hovenkamp, Antitrust Policy After Chicago, 84 Mich. L. REv. 213, 223 (1985). Although some have characterized Continental TV, Inc. v. GTE Sylvania Inc., 433 U.S. 36 (1977), as evidence of the Court's adoption of economic efficiency as the unrivaled rationale for that particular case, the Court's reference does not constitute a commitment to wcalth maximization.

First, the language of the opinion refers not to allocative efficiency, but instead to productive efficiency-that is, to "allowing the manufacturer to achieve certain efficiencies in the distribution of his products." Id. at 54. There is no necessary relationship between productive efficiency and allocative efficiency unless we have perfect competition. Peritz, supra note 3, at 1290 . Moreover, the Court did not take into aecount the productive efficiency effects on distributors and dealers; nor did it offer any rationale for choosing the manufacturer's productive efficiency interests over those of its distributors and dealers. Perhaps the Court presumed that the manufacturer made some detcrmination of overall productive efficiency based on its economic interest in minimizing the retail price to maximize its (derived) demand.

Second, there is no theoretical basis for asserting that "frec riders" are inconsistent with wealth maximization. For example, to the extent that a promoting retailer can sell a product and services for a higher price in one inarket and a discounting retailer the same product without services in a second (isolated) market, the manufacturer could expect greater dernand, im much the sane way that price discrimination generates greater demand. As we know, price discrimination can be wealthmaximizing behavior.

157. See infra notes 181-92 and aecompanying text. 
Finally, what can we learn about the content and the implications of the asserted paradox between efficiency and populism?

\section{The Relationship Between Wealth Maximization and Competi-} tion. Although price theorists do not agree on one meaning for efficiency, most of the time price theorists claim they mean wealth maximization. In short, they assert that antitrust pohicy should serve only the goal of maximizing the cumulative market value of goods, services, good will, and other private property. There are serious difficulties with this formulation, beginning with the allocation of property rights, the identification of winners and losers, and the quantification of gains and losses. 158 Antitrust scholars and others concerned with such problems already have surveyed this ground with great care and their steps need not be retraced. ${ }^{159}$

What does merit further attention is the asserted relationship between wealth maximization and competition policy. Two familiar formulations have been offered by Richard Posner. ${ }^{160}$ Although both conclude that competitive markets are the proper mechanism for maxiimzing the cumulative value of private property, each has a shightly different emphasis, whose implications become clear when analyzed within the rhetorical franework of competition policy and private property rights.

First, Posner in his well-known book, Antitrust Law: An Economic Perspective, states that "since, in an economic analysis, we value competition because it promotes efficiency-i.e, as a means rather than as an end-it would seem that whenever monopoly would increase efficiency it should be tolerated, indeed encouraged."161 In short, the traditional

158. See, e.g., Peritz, supra note 3; cf. Symposium on Efficiency as a Legal Concerm, 8 HofsTRA L. REV. 485 (1980) [hereinafter Symposium].

159. Hovenkamp, supra note 156, at 231-33 (observing that efficiency as wealth maximization ignores the way that wealth is distributed, and the identity of the gainers and losers become irrelevant); Symposium, supra note 158 (especially Kennedy \& Michelman, Are Property and Contract Efficient?, at 711; Colennan, Efficiency, Utility, and Wealth Maximization, at 509; Kornhauser, $A$ Guide to the Perplexed Claims of Efficiency in the Law, at 591; Dworkin, Why Efficiency?, at 563; Baker, Starting Points in the Economic Analysis of Law, at 939).

160. There have been numerous others as well. Perhaps the clearest formulation belongs to Robert Bork. Bork avoids all of Posner's difficulties by first defining productive efficieucy as business success, then by defining his refereuces to efficiency as calls to productive efficiency. R. BoRK, supra note 72, at 91, 104-06 (1978). Thus, the only proper policy implication of Bork's transparent formulation is free-marketeering - that is, no antitrust intervention. If the practice is successful, it is effcient and should be applauded. If the practice is unsuccessful, why waste enforcenent resources? For an extended critique of this sort of circularity, unencumbered by history, by empirical study, or by useful logic, see, e.g., Adams \& Brock, Reaganomics, supra note 79, at 323-39.

161. R. POSNER, supra note 155 , at 22 . I will take Posner to mean wealth maximization, even though he sometimes seems to mean productive efficiency and other times Pareto Optimality. For the clearest statement of efficiency's meaning as wealth maximization, see R. POSNER \& F. EASTER- 
view of competition as an important end $\mathrm{m}$ itself is turned on its head: Competition is valued only when it serves wealth maximization. That is, competition is valued only as a means for imcreasing the cumulative market value of private property.

This sort of justification for rules promoting coinpetition, inonopoly, or any other state of affairs might appear to be a modern form of utilitarianisin: A rule is Good when its effect is a society that, overall, is better off (wealthier). Even if we ignore the classical criticisins of utilitarianisin (even if we agree, for exainple, that society overall being better off is inore important than some individuals being worse off) wealth maximization does not help us accomplish this goal. Here is one reason that wealth maximization does not tell us whether society overall is better off: While utility purports to take into account any and every preference, wealth maximization takes into account only those that can and are exercised in commercial markets. In consequence, three effects result: non-econoinic goals are ignored, those without the wealth to vote for their preferences are ignored, and those who believe that their votes in political inarkets serve to protect their non-economic preferences are ignored. A good example of the first and third is clean air or water, a non-economic preference that is considered a public good, as regulated by environmental legislation. A good example of the second instance is the poor person who "prefers" canned dog food to canned stew, or a public shelter to an apartment overlooking Central Park. In all three instances, wealth inaximization does not give us a useful picture of how society's resources are allocated or an appealing account of how they should be. While wealth may be an important social good, it is not the only Good that our society values. ${ }^{162}$

Thus, the clioice of maximizing the value of private property in commercial markets is not neutral. It turns out to be just another pohtical choice, whose claim to priority requires justification: Why choose wealtlı as the value to be maximized and why maximization as the standard for evaluation? For example, wliy clioose a possibly efficient monopoly (which Posner both chooses and portrays as economically unlikely) over the multiple virtues of sinall busmesses? Or, wliy permit

BROOK, ANTTTRUST CASES AND MATERIALS 9-10 (1980). For a critical analysis of Posner's efficiency logics, which lead to an efficiency nightmare of productively inefficient doininant firms, see Peritz, supra note 3, at 1287-92.

162. Kennedy \& Michelman, Are Property and Contract Efficient?, in Symposium, supra note 158, at 721-23. See generally Michelman, Property, Utility, and Faimess: Comments on the Ethical Foundations of "Just Compensation" Law, 80 HARv. L. REv. 1165 (1967) (arguing that courts' determinations of when government action constitutes a taking diverges from traditional notions of utility and fairness). Nor is it a proxy for a utilitarian summation of society's preferences, assuming the possibility of quantification and cumulation. 
producers to impose vertical restraints on independent retailers? If the answer is "because it maximizes wealth," then the respondent must make a inoral arguinent about why wealth maximization is inore important than economic opportumity or wealth transfers or any other policy preference that traditionally has been associated with antitrust. ${ }^{163}$

In formulating a second relationship between competition and wealth maximization, Judge Posner seems to have recognized this need to justify the normative ground of price theory. In an article attempting to re-ground price tlieory in liberal theory and to distinguish wealth maximization from its utilitarian cognate, Posner has alluded to something along the lines of Kantian personal autonomy. ${ }^{164}$ Although the reference is vague, in that neither definition nor citation to Kant is given, it is clear

163. For an example of the view that Congress has chosen to give preference to small busimesses, see United States v. Aluminum Co. of Am., 148 F.2d 416, 436 (2d. Cir. 1957). See also United States v. Von's Grocery, 384 U.S. 270 (1966); Brown Shoe Co. v. United States, 370 U.S. 294 (1961). For examples of the view that antitrust doctrine has evidenced a commitment to preserving $\mathrm{m}$ dependent retailers' freedom to do business as they choose, see Continental T.V., Inc. v. GTE Sylvania Inc., 433 U.S. 36, 61-62 (1977) (White, J., concurring); Business Elecs. Corp. v. Sharp Elecs. Corp., 485 U.S. 717, $748-57$ (1988) (Stevens, J., dissenting).

164. Posner, Utilitarianism, Economics, and Legal Theory, 8 J. LEgAL STUD. 103 (1979). In some sense, Posner attempts a synthesis of utilitarian and libertarian ethics, much as Vilfredo Pareto attempted in his 1909 work on allocative efficiency. Here is a thumbnail sketch of the intellectual history to contextualize both attempts. The classical utilitarian ethic is majoritarian: If a rule or policy makes society, on balance, better off, then it is a good rule or policy. A hbertarian critique would focus on those who are not better off. Kant, for example, argued against utilitarianism by asserting that people should be treated as ends, not means. A utilitarian ethic was unacceptable, im part because it treated individuals as neans to an end of a better society. Skipping a few centuries, we can understand Pareto's 1909 work, Manuel d'Economie Politique, as an attenipt to resolve this conflict: A rule or policy should be considered efficient if at least one person is better off and no one is worse off. This is the standard economic notion of allocative efficiency. Note that in this sense of efficiency, society is better off because at least one individual is better off, and no one is worse off.

Thus, Paretan efficiency can be understood as an attempt to synthesize utilitarian and libertarian ethics. The problen, of course, is the inpossible burden inposed on policymakers and rulemakers: If anyone is worse off, the recommended change is imefficient. The more recent fonn of Kaldor-Hicks or potential Pareto efficiency can be understood as an atternpt to formulate a workable standard of efficiency. This forn of cost-benefit analysis is termed potential Pareto efficient becanse a surplus of benefits over costs suggests that winners could pay losers. They need not pay anyone. But because they could and still, as a class, be better off, the Kaldor-Hicks standard is met. Of course, this formulation re-introduces the problem of losers that libertarians found unacceptable in utilitariarisun. Using wealth as the value, rather than utility, would seem to offend both camps. Utilitarians would not recognize wcalth as an adequate presentation of utility. Libertarians would view the wealth maximization form of cost-benefit analysis as sharing the defect of utilitarianisn's view of individuals as means not ends.

Posner attenipts to fonnulate a new synthesis by linking wealth maximization directly with the Kantian notion of personal autonony - a restatement of the libertarian ethic of individual liberty. Posner's attempt at a synthesis of marketplace liberalism and libertarianism is notable, if at all, becanse it fails so disınally. It leaves us with precisely the same set of questions about the relationship between individual liberty and soeial good, at least within the constraints of choosing between utilitarian and libertarian ethies. 
that this so-called "Kantian" turn is an attempt to re-ground price theory in an ethic of mdividualism.

Here is a summary of the argument. In brief, Posner claims that wealth maximization can be understood as a liberal value because it is the product of market transactions between willing buyers and sellers. An individual willingly enters into a market transaction (or otler transactions that Posner describes as market-like) only when she believes that she will be better off than she is before the transaction. If the transaction results in a loss, then we can assume that she ex ante consented to the (risk of) loss. Posner claims, therefore, that all consensual market transactions are conduct serving the Kantian notion of personal autonomy (and, presumably, the libertarian notion of individual liberty). Thus, market transactions, because they instantiate the ideal of personal autonomy, should be the rule. Moreover, we already know that market transactions, free of government intervention, maximize wealth. With an idealized image of free competition as the connecting link, the chain is complete: On one side, personal autonomy is hinked to free competition. On the other, wealth maximization is also linked to free competition. By some commutative principle of logic, personal autonomy and wealth maximization are linked. The inference is that wealth maximization can serve as a proxy for personal autonomy. In consequence, the goal of wealth maximization is a neutral principle, even though some individuals lose wealth. It is neutral because the free competition required for wealth maximization is, at the same time, a mecharism that permits every participant to exercise personal autonomy. In short, wealth maximization supports a commitment to liberty. ${ }^{165}$

Posner's first formnlation of wealth maximization as a social good is an appeal to the property rhetoric of enabling society to mcrease the value of its holdings. This social good is defined as depending on a competition rhetoric disciplined by a commitment to liberty-that is, as depending on free competition. In his second (libertarian) forınulation, this property rhetoric is legitimized by, again, linking it to a competition rhetoric driven by a commitment to liberty-to competition free of govern-

165. What is interesting about this formulation is that it seems to recoup the loss suffered in the move from the traditional Pareto Optimality standard to the Kaldor-Hicks version of allocative efficiency. That is, the appeal of the Paretan determination is its dependence on the fact that no one. is worse off-pretty close to a neutral standard. Kaldor-Hicks allows for losers, as long as there is a net gain. With the turn to "personal autonomy," Posner can claim that even losers are better off. It is the process that is good, even when the result is not. Even losers are winners, just for the taste of it, just for the enjoyment of exercising one's commercial preferences.

I leave to another day a detailed Kantian critique of Posner's questionable sense of "personal autonomy." For three excellent articles that provide ground for an extended critique, see Kennedy, Legal Formality, 2 J. LEGAL STUD. 351, $371-77$ (1973); Massey, Kant on Self-Respect, 21 J. HisT. PHIL. 57 (1983); Richards, Rights and Autonomy, 92 ETHICs 3 (1981). 
ment intervention. But in the latter, the commitment to liberty is itself legitimized by reference to the liberal philosopher Kant. In sum, the two formulations draw connections among competition and property rhetorics, and liberty.

Liberty is the connective tissue in Posner's two formulations of wealth maximization. In particular, liberty of contract provides the link between his property and competition rhetorics. The rhetorical limits of this commitment to liberty become clear when one recognizes that neitler formulation inentions equality. A commitment to equality is absent from both competition and property rhetorics in both formulations of wealth maximization. Indeed, as we shall see, it is populism that displays a commitment to equality. For Posner, Bork and others, it is an asserted conflict between commitments to liberty and equality that underlies the paradox invented between wealth maximization and populism, between economic and sociopolitical concerns.

2. The Relationship Between Populism and Competition. Posner's Antitrust Law: An Economic Perspective provides a useful starting point for summarizing an influential price theorist's view of the relationship between populism and competition. ${ }^{166}$ Under the leading of "Sociopolitical Objections to Monopoly," Posner recounts two non-"economic" objections to monopoly, each of which involves a form of redistribution. First, "monopoly transfers wealth from consumers to the stockholders of monopolistic firms."167 In other words, one populist (but for Posner, non-"economic") concern is the wealth transfer associated with monop-

166. R. POSNER, supra note 155. In some ways, Robert Bork's rhetorical excesses may be more eutertaining than those of Posner, if not more enlightening. He calls the Clayton Act's introduction of populism the " 'Typhoid Mary' of the protectionist disease." Bork, The Place of Antitrust Among National Goals, in NAT'L INDUS. CONFERENCE BD., BASIC ANTITRUST QUESTIONS IN THE MidDLE SiXTIES, FIFTH CONFERENCE ON THE IMPACT OF ANTITRUST ON ECONOMIC GROWTH 18 (1966). Whatever Bork might have meant by populisin, popular and populist concerns were evident as early as the Sherman Act's legislative debates. See, e.g., Peritz, supra uote 1, at 285.

167. R. POSNER, supra note 155 , at 18 . The text claims and later mounts an argument that the wcalth transfer from consuners does not end up in the inonopolist's pockets because it is "dissipated in the purchase of inputs into the activity of becoming a monopohst." Id. In other words, we don't have to worry about mouopolists getting rich because they spend the inoney on the socially wasteful and productively inefficient activity of maintaining their monopoly. Somehow, that does not make me less concerned either about mouopolies or about the associated wealth transfer. For a critique of Posner's claim, see Shepherd, supra note 79, at 401, 411-14.

The text also recounts a "second argument" about fostering collusion "to manipulate the political process to obtaiu protective legislation ained at increasing the industry's profits." Id. For my purposes, insofar as the aim is the transfer of wealth from consumers to producers, I treat this second argument as a restatement of the first. 
oly. 168 Although a populist policy to create competition-for example by dissolving the monopohist to create several firms of roughly equal size-would seem to be a logical mechanism for reversing this transfer of wealth, it is not. This connection between populism and competition is illusory because, as Posner has already informed us, the wealth transferred to the inonopoly might be efficient-that is, it might be wealthmaximizing. Thus, a rule based on a pohicy to redistribute wealth from monopolies to consumers, a policy to equalize wealth, could be inefficient. Any argument to equalize competition by, for example, restructuring an industry, that has as its purpose redistribution of wealth is inefficient and, by Posner's definition, populist. It is a commitment to equality that identifies the argument or objection as populist.

Posner's second example of a non-"economic" objection to monopoly is the "policy of restricting the freedoin of action of large business firms in order to promote small business." 169 An asserted conflict between commitments to liberty and equality underlies the very logic of Posner's second formulation of "populism"-that the policy of favoring coinpetition among numerous and roughly equal firms is built upon the practice of restricting large business firms' liberty of contract. According to this view of "populism," a commitment to equalizing rivalry, to establishing workable competition, is antithetical to liberty of contract, to laissez-faire competition, and thus, to wealth maximization. Though inany controversial claims underlie Posner's second characterization of "populism," for the sake of brevity, only two will be addressed here.

First, there is the exphicit claim that "populism's" coinınitınent to equality is founded on a rejection of (big business firms') liberty. This claim makes sense, of course, only because Posner assumes that competition always insinuates hiberty and that equality is always antithetical to liberty. Only if botil of these assumptions hold does "populism" then conform to Posner's characterization. But neither assumption stands up to scrutiny. To begin, it is not clear that competition always insinuates liberty. For example, enjoming the merger of all firms in an industry can, but need not, be seen as pro-competitive and anti-liberty (of contract). Even if one beheves that competition always insinuates a coinunitment to hiberty, hiberty and equality need not be seen as antitletical. Indeed, it is a commonplace that liberty and equality are always interdependent, that eacls requires the other as a condition for its livelihood. For example, the greater a dominant firm's market power, the more it

168. Insofar as the distribution of wealth is an issue that can be separated from wealth maximization, Posner calls it a political or populist concern. For a discussion of efficiency's dependency on the distribution of wealth, a well-known relationship, see, e.g., Peritz, supra note 3, at 1292-95.

169. R. POSNER, supra note 155 , at 19. 
diminishes the liberty of rivals, customers, and suppliers. Redistributing market power to equalize it would mcrease liberty. Indeed, one could even say that it would "maximize" liberty, thougl it would leave soine worse off. In short, it is not self-evident that "populism's" commitment to equality precludes a commitment to liberty. Posner's view notwitlstanding, "populism" can be seen as being entirely compatible with competition, liberty, and equality.

Second, Posner's version of "populism" is founded on an unspoken and controversial assumption that efficiency varies directly witlı size. 170 Thus, competition on tlie merits (whatever that means) would favor large business firms. Another inference froin his assumption is that small firms, to survive, must be protected from more efficient large ones. The assumption underlying this inference lias no basis in fact, altlougli it does tend to justify bigness. To the contrary, empirical studies tend to show that large firms are less efficient. ${ }^{171}$

Moreover, there is the dark underside of Ronald Coase's theory of the firm. ${ }^{172}$ Coase asserts that a firm's size is a function of efficiency. ${ }^{173}$ That is, a firm will expand as long as production by fiat is more efficient than production by market transactions. Until the certainty of the former becomes more costly than the information lost, the firm will contimue to expand. The theory assumes that viable competitive markets are producing valuable information. But as markets become less competitive, the information becoines less valuable. In consequence, greater efficiency losses associated with increased firm size are tolerable because less information is lost. There is a momentuin that builds: As market structure becoines less competitive, firms are less constrained by the opportunity cost of lost information when assessing the tradeoff between fiat and contract. In short, the tendency toward concentration increases. ${ }^{174}$

Even in those situations in whicl Coase's theory of the firm makes sense, tlie practice can be mucli more complex. For example, Coase ignores the propensity to overvalue certainty and the firm's desire to insulate itself from market discipline. Thus, it seems, the success of large businesses cannot be attributed categorically to efficiency. One plausible alternative inference from the facts is that sucli success is based instead on tlie "background" rules, including contract, tort, and property law.

170. R. POSNER, supra note 155, at 19. See also Blake, Conglomerate Mergers and the Antitrust Laws, 73 ColuM. L. REv. 555, 570 (1973) (preferential access to capital resulting from conglomerate mergers threatens a probable mjury to competition).

171. See authorities cited supra note 79.

172. Coase, The Nature of the Firm, 4 Economica 386 (1937).

173. Id.

174. See generally United States v. Von's Grocery, 384 U.S. 270 (1966); Brown Shoe Co. v. United States, 370 U.S. 294 (1961). 
In other words, what we call "hiberty of contract" might favor large firms so much that some smaller firms' efficiency advantages are lost. If large firms are permitted to enter into contracts "freely," then for example, a large firm can sell below cost to drive a more efficient local firm out of busmess and recoup its losses from monopoly profits in uncontested locations. A (populist) policy of "protecting" local firms from such practices would be consistent with competition on the merits. Here at least, popuhsm, (productive) efficiency, and competition are entirely compatible. Nonetheless, following Posner's "economic" "logic" of wealth maximization, restricting the hiberty of large firms would be anti-competitive and inefficient. ${ }^{175}$

It appears that both wealth maximization and populism can be compatible with competition. This is the true paradox, price theory's formulation notwithstanding. Populism is no more anti-competitive than wealth maximization. Both enjoy strong rhetorical counections to competition policy. The conflict between wealth maximization and populism rests on the tension between commitments to liberty and equality. It is a tension captured in the conundrum of "free competition." Price theory rests on a preference for liberty of contract and the associated ideal of competition free of government power. Populism rests on a preference for eliminatimg gross inequalities and the associated ideal of competition free of private power. Price theory proceeds from an unmitigated commitment to mdividual hiberty, which is understood as antithetical to a commitment to equality. In sharp contrast, populism adheres to the view that a strong commitment to equality is entirely consistent with a strong commitment to individual liberty. ${ }^{176}$

Whatever else price theory has accomphished, it has not solved the paradox of competition. Instead, one of its leading proponents, Robert Bork, has invented a false paradox to which Richard Posner and other

175. Although Posner does point out that firms taking in monopoly profits have an incentive to expend resources to protect these profits from other firms, and that such costs are socially wasteful, the observation leads nowhere. It leads nowhere because, as a practical matter, all that the monopoly firm is doing is competing. There are only two alternatives-either not allowing the dominant firm to compete or limiting the modes of competition. First, Posner obviously would not invoke a rule to stop powerful firms from competing; even if he did, how could he enforce the rule? If instead, he wonld limit the ways in which a monopoly can compete, he would be doing nothing different from the limited and ineffective "rule of reason" analysis he has suggested elsewhere. POSNER, supra note 155, at 12-15 (social cost of competing for monopoly); id. at 184-96, 211 (Sherman Act section 2 analysis).

176. For a closely-reasoned argument demonstrating that neither private property nor freedom of contraet regimes are necessarily more efficient than state-of-nature or forced-sharing-for-need regimes, see Kennedy \& Michelman, supra note 158, at 712. Of course, there are other notions of equality, some of which might be compatible with a primary commitment to liberality of contraetnon-discrimination, for example. The point remains, however, that Posner is committed to liberty of contract first and foremost. 
price theorists subscribe. ${ }^{177}$ Moreover, as I have shown in another context, both efficiency and populism are understood most usefully as products of the rhetorical forces of competition policy and private property rights. ${ }^{178}$ Both price theory and populism include a politics of wealth distribution: Both a regime of liberty of contract and a regime committed to recognizing the impact of economic power in bargain transactions produce predictable patterns of wealth distribution. Finally, both price theory and populism have strong yet complex relationships with "free competition." The complexities result from differing views of the connections between economic liberty and commercial equality.

\section{Recent Scholarly Attention to the Formative Period: Toward a Fourth DisagreEment About COMPETITION}

This Section chronicles a new wave, if not a new era, of antitrust scholarship whose common movement is a (re)turn to antitrust's earhest period. That turn then serves as the context for a genealogical approach to antitrust. Finally, the Section concludes that a genealogical approach leads us to a fourth disagreement about competition, a disagreement that is already evident in pohicies considered and adopted.

Price theory's appeal seems to have been two-dimensional: first, there is the appeal of its normative foundation, usually called "consumer welfare"; second, there is the attraction of its methodological claims of certainty. Because the phrase "consumer welfare" shares semantic elements with the Ralph Nader consumerist movement, there has been a feeling that Robert Bork, Richard Posner, and other price theorists share the Naderites' concerns for consumers. Nothing could be farther from the truth, we have learned. Where Naderites call for commercial firms to take social responsibility for their products, services, and effects on society, price theorists beheve that firms only have a responsibility to their shareholders to maximize earnings. "Consumer welfare," for price theorists, means laissez-faire capitalism-economic activity free of democratic constramts. Even those unfamiliar with price theory havc seen its impact in the Reagan years, especially evident in the reticence of federal enforcement agencies, whether the Department of Justice's Antitrust Division or the Environmental Protection Agency, to prosecute corporate violators of the law. We simply cannot be confident that powerful producers' interests correlate with consumer well-being or other civic concerns. Even if we were so confident, consumer well-being can be inconsistent

177. See supra text accompanying notes 158-76.

178. Peritz, supra note 1 , at 289 n.22. 
with other individual and social interests. Wealth maximization seems to be an impoverished ethic.

Many recognize that price theory is a legacy of the classical econounics in decline a hundred years ago, at the time of the Sherman Act's passage. Its legacy is not only normative but also inethodological. Price theory shares classical economics' assumptions and behefs about the way markets (and thus, the world) works. More than that, price theory is a formalistic enterprise rooted in a pre-Realist view of legal reasoning. To the extent that Robert Bork, for example, beheves that a turn to the general principle of efficiency, or even a less general principle of wealth maximization, can inake antitrust law coherent, he is ignoring Justice Holines's well-worn aphorisin that general principles do not decide concrete cases. Bork and his fellow neo-classicists are asking us to buy imto a inechamical jurisprudence long-ago disımissed as inadequate and misleading. ${ }^{179}$ Furthermore, we inoderns understand that legal reasoning calls for analogical and inductive analysis, not just the deductive formalism so often seen in price theory practices. Thus, theoretical price analysis seens too limited and too unrealistic in its practice.

In addition to being dissatisfied with price theory's claims of nornative and inethodological value, soine perceive a similarity in the political economic climates of 1890 and 1990. In 1890, Jolin D. Rockefeller could ignore an Ohio Supreine Court decision upholding the state's right to dissolve the Standard Oil Trust. He smiply picked up his corporate forinalities and inoved to New Jersey. ${ }^{180}$ Today, a number of inultinational corporations are bigger and inore powerful than inany nation-states. At the very 1cast, inultinational corporations are capable of inoving quickly to take advantage of opportune differences in their supply and demand inarkets. To the extent that firms are able to demand and secure favorable legal regimes, they are politically unaccountable. They can pack their passports and their corporate formalities, and inove out of a

179. See, e.g., Cohen, Transcendental Nonsense and the Functional Approach, 25 CoLUM. L. REV. 809, 812 (1935) (when metaphors of traditional jurisprudence become reasons for decisions rather than devices to formulate decisions, one is "apt to forget the social forces which mold the law and the social ideals by which the law is to be judged"); Flynn, supra note 72, at 264 (in the Bork reading of the legislative history, "a latter-day economic theory is being used to translate tlie basic values the Congress which adopted the Sherman Act sought to preserve into the narrow and rigid values underlying one brand of current economic theory"); Peritz, supra note 3, at 1249 (finding Bork's claims "historically, practically, and theoretically unsound"); Pound, Mechanical Jurisprudence, 8 Colum. L. REV. 605, 606-07 (1908) (warning of the dangers of a seientific legal system in which the ghosts of departed masters dominate: "[T] unsound conclusions are held for gospel").

180. See H. Thorelli, the Federal antitrust Policy: Origination of an American TRADITION 82 (1955). 
country. There is reason some are deeply troubled by such corporate unaccountability.

For a growing number of antitrust scholars and practitioners, dissatisfaction with price thcory and a reluctancc to return to the "constitutional" jurisprudence that preceded it has led to a search for alternatives. A surprisingly large number of scholars have turned to historical analysis. ${ }^{181}$ Perhaps the turn reflects a reaction to price theory's static analysis, its refusal to take into account changes in context. The wealth of historical analysis also indicates a resistance to Robert Bork's wellknown attempt to overcome the generally accepted direction of time and argue that the Sherman Act was passed for purposes not historically possible. This fable made an easy target for inore careful students of antitrust history, including John Flynn, Eleanor Fox, Robert Lande, and David Millon. ${ }^{182}$

Associated with these historical critiques were several different kinds of histories, written about the formative years of antitrust, typically 1890 to 1914 or 1918. David Millon has written a political history of the formative years that traces the Sherman Act's roots to both liberal and republican conceptions about political econoiny. ${ }^{183} \mathrm{He}$ has captured the relationship between the cultural context of populisin and the material

181. Of course, other sorts of critiques have appeared as well. See L. Sullivan, ANTITRUST (1976); Curran, Beyond Economic Concepts and Categories: A Democratic Refiguration of Antitrust Law, 31 ST. LouIs U.L.J. 349, 349 (1987) (economic efficiency in antitrust law is one of the "rational concepts [which] are first perceived as modes of constructive thought, but ultimately become doctrines that limit options and block alternatives, destroying justice and democracy"); Flynn, supra note 72; Harris \& Jorde, Antitrust Market Definition: An Integrated Approach, 72 CALIF. L. REv. 1 (1984) (criticizing existing market definitions and suggesting a more sophisticated approach to market definitions in antitrust matters); Hovenkamp, supra note 156; Lande, supra note 4, at 68 ("Congress passed the antitrust laws to further economic objectives, but primarily objectives of a distributive rather than of an efficiency nature"); Ponsoldt \& Lewyn, Judicial Activism, Economic Theory and the Role of Summary Judgment in Sherman Act Conspiracy Cases: The Illogic of Matsushita, 33 ANTITRUST BULl. 575 (1988); Salop, New Economic Theories of Anticompetitive Exclusion, 56 ANTITRUST L.J. 57 (1987) (suggesting a theory of anticompetitive exclusion which allows competition that benefits consumers and deters exclusionary conduct harmful to consumers); Scherer, Review, supra note 79 (criticism of the "Antitrust Unorthodoxy" in Posner's book, ANTITRUsT LAW: AN ECONOMIC PERSPECTIVE (1976); Spivak, supra note 20; Sullivan, The Economic Jurisprudence of the Burger Court's Antitrust Policy: The First Thirteen Years, 58 NOTRE DAME L. REV. 1 (1982) (comparision of Burger Court's antitrust jurisprudence with the antitrust precedents and established twentieth century jurisprudential models).

182. John Flynn has argued skillfully that Robert Lande's economistic reading of the antitrust laws' legislative histories as paeans to consumer wealth transfers suffers the same infirmity of historical analysis. See Flynn, supra note 72 , at 264 . Nonetheless, I believe that Lande's convincing refutation of Bork's claims has provided a valuable service to antitrust scholars and policy makers. See Lande, supra note 4, at 65; Fox, The Modernization of Antitrust: A New Equilibrium, 66 CORNELI L. REV. 1140 (1981).

183. Millon, The Sherman Act and the Balance of Power, 61 S. CAL L. REv. 1219, 1220 (1988) (the Sherman Act was a final effort on behalf of a long standing tradition-copposition to monopoly power and faith in the efficacy of competition to prevent it"). 
conditions of existence, namely the emergence of powerful and frightening accumulations of capital. We are reminded that individual feelings of powerlessness are not just symptoms of postmodernism, and that the Sherman Act was conceived as a mechanism for righting the imbalance between political and economic spheres. James May devoted one section of a paper to a history of state antitrust law in a formative era-an account of "The Other Half of Antitrust: State Statutory and Cominon Law, 1880-1918." In this paper, May sought to retrieve the economic logic of the era im order to provide a fuller context for understanding early federal antitrust law, as well as to take issue with Robert Bork's view of those years as devoid of economic analysis. ${ }^{184}$ This investigation allows us to "remember" the logics then associated with competition policy. Herbert Hovenkamp, im his assessment of econormic analysis of antitrust, devotes a section of the essay to "The Role of Economics in Federal Antitrust Pohicy: 1890-1980."185 As Frederick Rowe ${ }^{186}$ did before him, Hovenkamp describes changes in antitrust analysis as related to paradigm shifts in modes of economic analysis. That is, Hovenkamp believes that "flaws in the Chicago model's basic premises will one day cause it to be eclipsed, just as previously ascendant doctrines have been echipsed."187 Economic and antitrust history are depicted as cycles driven by paradigm shifts.

Each of these careful studies seeks to expand the limits of antitrust discourse. Eacl historicizes the prevailing view and then reacles back in time to recover arguments, policies, and visions echipsed by the ascendancy of new views and by the passage of time. The same can be said of the historical critiques of Eleanor Fox, Robert Lande, and John Flynn. Eleanor Fox finds strong evidence of a concern for the competitive process. ${ }^{188}$ John Flym lias remarked that the competitive process can be understood as a means of allocating property rights. ${ }^{189}$ Robert Lande makes a persuasive claim that the antitrust laws were passed to protect consumers from wealth transfers associated with monopoly pricing. ${ }^{190}$ Eacli of these historical investigations corroborates the view that anti-

184. May, Antitrust Practice and Procedure in the Formative Era: The Constitutional and Conceptual Reach of State Antitrust Law, 1880-1918, 135 U. PA. L. REv. 495, 497-507 (1987).

185. Hovenkamp, supra note 156 , at $217-26$. For a more recent historical analysis that follows themes earlier explored in Peritz, supra note 1, Peritz, supra note 3, Millon, supra note 183, and May, supra note 184, see Hovenkamp, The Sherman Act and the Classical Theory of Competition, 74 IOWA L. REv. 1019 (1989).

186. Rowe, The Decline of Antitrust and the Delusions of Models: The Faustian Pact of Law and Economics, 72 GEO. L.J. 1511 (1984).

187. Hovenkamp, supra note 156, at 213.

188. Fox, supra note 182.

189. Flynn, supra note 72.

190. Lande, supra note 4. 
trust discourse always has included arguments founded in coinpetition rhetoric rather than wealth maximization. Moreover, each authenticates the view that antitrust law has embodied precisely the social policies that Posner and other price theorists dismiss as "populist." Each offers strong evidence of persistent regard for the process of competition, monopoly prices, and the virtues of small and medium-sized business firms. These concerus are populist in the familiar sense that Congress passed major legislation in $1890,1914,1936,1950$, and 1975 to promote these values. In this familiar sense, price theory's anti-populism is also anti-democratic.

All of this historical scholarship provides the context for another kind of history of antitrust law-what I call a genealogy or counter-history of antitrust discourse. This approach differs in three ways from most of the historical works described above. First, its focus is legal discourse or rhetoric. What emerges is an account of the historical changes in antitrust argument, changes im the ways lawyers, judges, and scholars have talked and written about antitrust law. These historical changes are taken apart and imspected under varying lights, mcluding the economic and pohtical views of the times.

Second, the approach is a counter-history, a history of forgotten claims and unheard arguments. It is the silent counterpart of traditional histories, the unseen twin of the familiar rhetoric of competition. This genealogy looks beyond or beside competition rhetoric to its counterpart-property rlietoric. This counter-history of competition policy is a history of private property rights. Its value is the powerful descriptive framework produced. It makes sense of historical and doctrinal problems either created by or left unanswered by both traditional antitrust analysis and price theory.

Third, a genealogy proceeds from a fundamentally different understanding of history. Traditional doctrinal and some historical analysis produces a cloistered, culture-free aceount of changes in legal doctrine. Its underlying assumption is that doctrine is progressing, getting better, or at the very least, that doctrine can be puslied in the "right" direction. Price theory produces what Arthur Leff has called a picaresque narrative, ${ }^{191}$ a history of law's heroic pursuit of efficiency. A genealogy calls into question the evolutionary and the picaresque views of history, neither of which comports with our experience or our analysis of antitrust law.

191. Lef, Economic Analysis of Law: Some Realism About Nominalism, 60 VA. L. Rev. 451, 451 (1974) (analogizing R. POSNER, ECONOMIC ANALYSIS OF LAW (1973) to a picaresque novel). 
Some recent historical studies, mcluding several works inentioned above, produce structuralist histories: They portray history as a series of paradigm shifts that underlie changes in antitrust doctrine. These efforts apply a useful and plausible historiography, particularly because the historical motor for change, the paradigm-shift, is understood as a pohticized process. ${ }^{192}$ Nonetheless, two unacceptable implications emerge: First, history is viewed as the process of one paradigm eclipsing another; second, nornal practice within a paradigm is characterized as synthetic, whereas revolutionary practice between paradigms is conflictual.

These imphications are unacceptable for a number of reasons. First, antitrust argument does not exhibit these tendencies. For example, this Article's account of disagreements over the meaning of competition shows that paradigms do not shift. Rather, traces, combinations, and permutations of earher arguments persist. They are not eclipsed; they are sometimes imprisoned and are always worthy of parole. Second, the analytical distinction between normal and revolutionary practices does not hold. Antitrust law and, for that matter, all law reflects conflictboth social conflict over policies and their consequences, and individualized conflict in the adjudication of disputes. If nornal practice were not conflictual, then Holmes would be wrong: General principles could decide concrete cases. Third, the view that there is one paradigm can blimd us to some of the conflicts taking place before our eyes. In antitrust, the widely-held belief that a competition paradigm always has provided the exclusive ground for antitrust obscures the textual fact that private property rights are always at issue in antitrust cases.

In sum, a genealogical approach allows us to represent the conflicts that always reside in the political artifacts of legal rules and policies. It helps to make us more resourceful lawyers and scliolars. It coinports more closely with our sense of political processes, whether legislative, administrative, or judicial. 193 Within antitrust discourse, a genealogical approach enables us to historicize current discourse, portray the folly of any depohiticized account, and retell stories of strugghe that comport with our experiences as lawyers, scholars, and members of political communities.

192. T. KuHN, supra note 15.

193. For a recent example of a thoughtful historical analysis that nonetheless fails to grasp the distinction between institutional and rhetorical history, see Cartensen, How to Assess the Impact of Antitrust on the American Economy: Examining History or Theorizing?, 74 IowA L. REv. 1175 (1989). 


\section{CONCLUSION}

In observing the Sherman Act's centennial, it is important to remember that antitrust law for most of its existence has been understood as a public interest law designed to regulate the exercise of private economic power. The historical animus for its enactment was the tidal wave of corporate consolidation, which took two forms-the holding company (then called the trust) and the cartel. In sharp opposition to the view held by modern price theorists and the Reagan-Bush administrations, Congress did not pass the Sherman Act to maintain the status quo, to constrain itself and the Executive from regulating market behavior. Rather, it passed the Sherman Act and ensuing legislation to resuscitate and sustain robust competition, which had been asphyxiated by holding coinpanies such as the Standard Oil Trust and overrun by cartels such as the Trans-Missouri Freight Association. ${ }^{194}$

Those representing the interests of the trusts and cartels argned that any regulation of their exercise of liberty of contract, whether inotivated by a desire to destroy rivals or to cooperate with them, was both unconstitutional and unreasonable. Nonetheless, the early "Literalists" determined that Congress had the power and the intent to subordinate these individual rights to the public interests furthered by coinpetition pohicy. Current per se offenses can be understood as legacies of this view. Under the "rule of reason," which has dominated antitrust discourse since 1911, courts have sought to mediate the tension between individual rights of hiberty and property, and public interests understood as cominitments to competition and equality.

Although, as I have already described, the tension is not so simple, the simplification is useful for summation purposes. It is useful for two reasons. First, in reminding us of property logic's role in the production of antitrust discourse, this distillation underscores the historical inadequacy and analytical limitations of the orthodox view that competition policy always has been the sole normative basis for antitrust. Second, it emphasizes the crucial role of hiberalism's fundamental tension between cominitments to liberty and equality. These two tensions-between competition policy and property rights, and between commitinents to liberty and equality - have produced the last century of antitrust law and policy. These four elements have armed history's conbatants in antitrust's own Hundred Years' War. Given this framework, I will conclude witl three cominents.

First, I intend to make no grand pronouncenients about the frainework or the gencalogical metlod, but only a few particular claims. I

194. See supra text accompanying notes 29-58. 
claim only that the framework and method have helped me in my earlier studies of antitrust's formative years and vertical restraimts doctrine, to settle some persistent problems left unresolved by traditional and price theoretical studies; in this Article the framework and method provide a basis for thinking differently about price fixing doctrine and for understanding the implications of Bork's invention and Posner's elaboration of an "antitrust paradox." Fimally, I have raised a few methodological questions about current antitrust historiographies. My second and third comments are offered as suggestions toward re-organizing price-fixing doctrime and as criticisms aimed toward scrapping the "antitrust paradox" and its misguided formulations of efficiency and popuhism.

Second, this Article's double history of price-fixing policy and doctrime under the "rule of reason" offers some helpful imsights for making sense of the area. To begin, it is clear that price-fixing has not been treated uniformly as illegal per se. There always have been "exceptions," which I characterize as the tangible artifacts of a much older counterpolicy associated with individual property rights-the protoplasm of our common law tradition. This counter-policy has been animated by a desire to help some commercial actors protect their property, to some extent, from the rigors of competition. One obvious exanple is the General Electric opinion's special treatment of common law consignment transactions, allowing the producer to retain title and thus to set retail prices. ${ }^{195}$ A more recent example is the $B M I$ opinion's characterization of the blanket license as a new product, thereby permitting the association to treat the bundle of copyrighted compositions as one product (rather than defining the association as a form of agreement among individual copyright holders). ${ }^{196}$

The counter-policy of individual property rights, which predates not only the Sherinan Act but also the Constitution, has been accoinpanied by variable effects on coinpetition policy. In General Electric, the producer had a virtual monopoly on the manufacture of electric light bulbs; by foreclosing the possibility of competition anong retailers, the Court pulled the plug on all competition in the industry. ${ }^{197}$ In $B M I$, the Court rhapsodized on the pro-competitive effects of blanket licensing of copyrighted compositions. ${ }^{198}$

The direct (though unexamined) consequence of this counter-policy is the effect on property rights theinselves. In functional terns, the Court's exercise of property logic (re)defines and thus, (re)allocates prop-

195. See Peritz, supra note 1; see also sources cited supra notes 130-37.

196. See supra text accompanying notes 115-29.

197. See supra text accompanying notes 130-33.

198. See supra text accompanying notes 115-29. 
erty rights ainong inarket participants. Retailers in General Electric were left with no ownership rights over the consigned items. ${ }^{199}$ In sharp contrast, BMI and ASCAP, in a position analogous to GE retailers, were deemed the producers and owners of a new product-the blanket hicense. Despite Justice Stevens' cogent dissent, the Court ruled that the copyright holders' hicensing arrangement not only created property rights for ASCAP and BMI but also left undisturbed copyright holders' individual property rights. ${ }^{200}$ One contrast between the two cases hes in the proliferation of property rights. In General Electric, the producer's rights were seen as antithetical to the retailers' rights-a zero-suin game of shifting property rights from one holder to another. In $B M I$, producers' rights were characterized as supplemented by retailers' new property rights-a positive-sum game of extending property rights from one holder to another.

If we beheve the Court in $B M I$, then the proliferation of property rights improved competition. If the Court in General Electric had allowed retailers to set prices, as the Court has done in some recent cases, ${ }^{201}$ then competition between dealers wonld have resulted. ${ }^{202}$ Is it possible that the proliferation of supply-side property rights can enhance coinpetition? On this principle, for example, intra-brand competition would be taken more seriously than it is in current vertical restramts doctrine. Lower prices provoked by enhanced coinpetition also wonld shift wealth froin producers to consumers. In General Electric, consumers probably had to pay more for hights and so were left with less wealth. A similar wealth transfer to consumers inght have resulted if the Court had adopted Justice Stevens' view im $B M I$.

A new analysis of price fixing would begin by looking not only at the competitive effects of antitrust doctrine but also at its impact on property rights. Experience in inore price-fixing cases and in other doctrinal areas would allow us to test hypotheses about the relationship between propexty rights and competition. For now, price fixing agreements shonld be presumptively illegal because such agreements decrease property rights and appropriate property. In more familiar ternns, they suspend competitors' obligations to make independent decisions about prices and they transfer wealth from consumers. My tentative view is that a defendant can overcome the presumption of illegality only by proving that the agreement diminishes neither competitors' property rights nor trading partners' property (wealth). Neither General Electric nor ASCAP/BMI

199. See supra text accompanying notes $130-33$.

200. See supra text accompanying notes 115-29.

201. See, e.g., Monsanto Co. v. Spray-Rite Serv. Corp., 465 U.S. 752 (1984).

202. For proposals to change vertical restraints doctrine, see Peritz, supra note 6. 
could have carried that burden and thus, their conduct would have been, in current terms, illegal per se.

Third, I think it important to recognize that the so-called "antitrust paradox" is a hoax. There is more to the hoax than the historical impossibility of wealth maximization as a late-19th century social policy, already uncovered in numerous careful studies of the period. There is inore to it than the associated methodological claim-the unperformable promise that adherence to efficiency "logic" will rationalize antitrust decisionmaking. As a matter of fundamental public policy, the "paradox" obfuscates the anti-competitive impact of price theory's form of efficiency-wealth maximization. It also obscures the strong connections between populism and competition. Moreover, it is clear that both "efficiency" and "popuhism" have significant "non-economic" effects; each produces a recognizable pattern of wealth distribution. At bottom, the "paradox" simply replays one familiar tension at the heart of liberal theory-the relationship between commitments to liberty and equality. Price theory takes one view of the tension as an unarticulated assumption: That a primary commitment to liberty is both justified and antithetical to a commitment to equality. That view is neither self-evidently true nor politically uncontroversial.

In short, re-instituting antitrust as public interest law calls for reasoned elaborations of populism's value-pluralism and efficiency's multiple meanings. It calls for a recognition of competition policy's relationship to private property rights- still observed but not articulated in recent Court opimions and scholarly writing. In particular, we must comprehend not only the competitive effects of market conduct, but also the distributive effects of antitrust doctrime-that is, the reallocation of property rights among producers, dealers, and consumers. Finally, we sliould not ignore the social and political by-products of conduct and doctrime, the comrections between individual liberty and equality. Whether im price fixing doctrime or agency merger guidelines, antitrust law produces and ratifies not only competitive but also distributive and socio-political effects. 